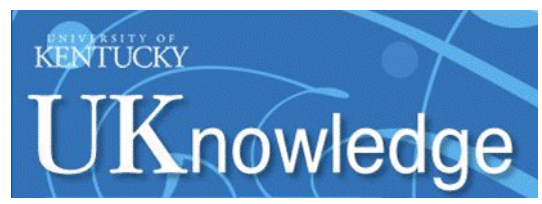

University of Kentucky

UKnowledge

$1-2018$

\title{
Autonomic Dysreflexia After Spinal Cord Injury: Systemic Pathophysiology and Methods of Management
}

Khalid C. Eldahan

University of Kentucky, khalid.eldahan@uky.edu

Alexander G. Rabchevsky

University of Kentucky, alexander.rabchevsky@uky.edu

Follow this and additional works at: https://uknowledge.uky.edu/physiology_facpub

Part of the Neuroscience and Neurobiology Commons, and the Physiology Commons

Right click to open a feedback form in a new tab to let us know how this document benefits you.

\section{Repository Citation}

Eldahan, Khalid C. and Rabchevsky, Alexander G., "Autonomic Dysreflexia After Spinal Cord Injury:

Systemic Pathophysiology and Methods of Management" (2018). Physiology Faculty Publications. 136.

https://uknowledge.uky.edu/physiology_facpub/136

This Article is brought to you for free and open access by the Physiology at UKnowledge. It has been accepted for inclusion in Physiology Faculty Publications by an authorized administrator of UKnowledge. For more information, please contact UKnowledge@lsv.uky.edu. 


\section{Autonomic Dysreflexia After Spinal Cord Injury: Systemic Pathophysiology and Methods of Management}

\section{Digital Object Identifier (DOI)}

https://doi.org/10.1016/j.autneu.2017.05.002

Notes/Citation Information

Published in Autonomic Neuroscience: Basic \& Clinical, v. 209, p. 59-70.

(c) 2017 Elsevier B.V. All rights reserved.

This manuscript version is made available under the CC-BY-NC-ND 4.0 license https://creativecommons.org/licenses/by-nc-nd/4.0/.

The document available for download is the author's post-peer-review final draft of the article. 


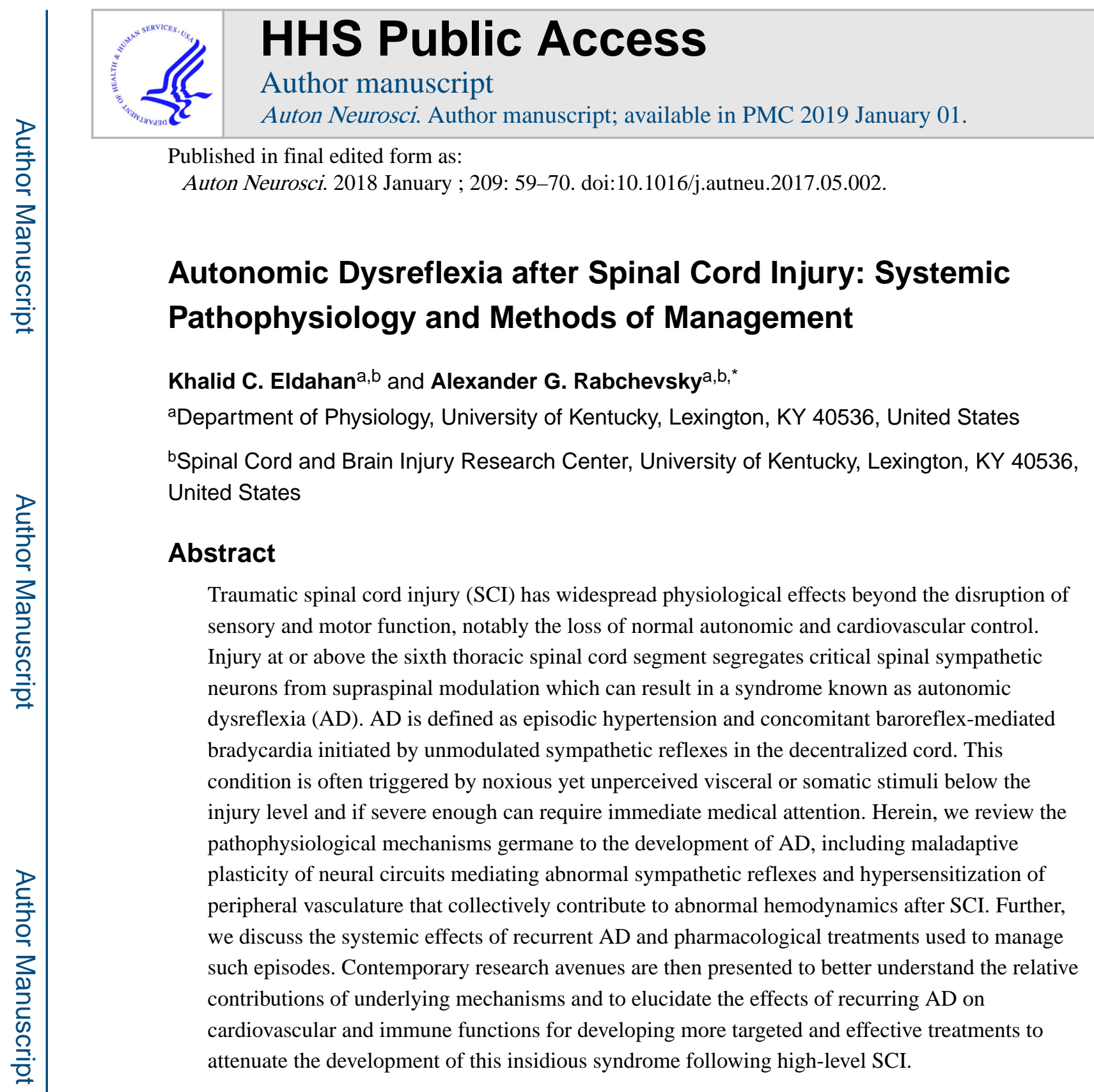

\section{Keywords}

maladaptive plasticity; sprouting; sympathetic; hypertension; propriospinal; primary afferent

\section{Introduction}

In addition to motor and sensory deficits, traumatic spinal cord injury (SCI) causes a constellation of interrelated autonomic and cardiovascular abnormalities. Cardiovascular

\footnotetext{
"Corresponding author: University of Kentucky, Spinal Cord and Brain Injury Research Center (SCoBIRC), B471, Biomedical and Biological Sciences Research Building, 741 South Limestone Street, Lexington, KY 40536-0509. agrab@uky.edu.

Publisher's Disclaimer: This is a PDF file of an unedited manuscript that has been accepted for publication. As a service to our customers we are providing this early version of the manuscript. The manuscript will undergo copyediting, typesetting, and review of the resulting proof before it is published in its final citable form. Please note that during the production process errors may be discovered which could affect the content, and all legal disclaimers that apply to the journal pertain.

Conflicts of interest: none.
} 
complications secondary to SCI are among the leading causes of mortality and morbidity in this population, underscoring the necessity to understand and properly manage resultant comorbidities (Cragg et al., 2013; Garshick et al., 2005; Myers et al., 2007; Sabre et al., 2013). In humans, SCI at or above the sixth thoracic (T6) spinal cord segment often results in the development of a potentially life-threatening syndrome called autonomic dysreflexia (AD). AD is clinically defined as acute hypertension generated by unmodulated sympathetic reflexes below the injury level that is often accompanied by baroreceptor-mediated bradycardia, which provides short-term control of blood pressure (Karlsson, 1999). In response to hypertension, the baroreflex system lowers blood pressure by reducing heart rate and decreasing activity of vasoconstrictor sympathetic preganglionic neurons (SPN) located throughout the thoracolumbar spinal cord that regulate peripheral vascular resistance. However, while vagal parasympathetic innervation of the heart remains intact after SCI, the disruption of descending vasomotor pathways to SPN produces an incomplete compensatory decrease in peripheral vascular resistance so that hypertension persists until the triggering stimulus is removed (see section 3.1).

Typically, AD is precipitated by noxious visceral or somatic stimulation below the level of injury that activates a massive sympathetic reflex causing widespread vasoconstriction. While the most common triggers are over-distension of the bowel or bladder (Canon et al., 2015; Lindan et al., 1980; Snow et al., 1978), other noxious stimuli including skin lacerations, ingrown toenails, pressure sores, tight clothing and certain medical procedures such as bladder catheterization and cystometry are also reported to cause AD (reviewed in Karlsson, 1999). During an episode of AD, arterial blood pressure can reach devastating levels, with systolic values as high as $325 \mathrm{mmHg}$ (McBride et al., 2003), exemplifying that $\mathrm{AD}$ is a hypertensive crisis that requires immediate medical attention (Muzumdar, 1982; Showkathali et al., 2007; Verghese, 1989). Severe cases that do not receive rapid and appropriate treatment can have serious consequences such as hypertensive encephalopathy, stroke, cardiac arrest, seizure and even death (Bjelakovic et al., 2014; Colachis et al., 1997; Eltorai et al., 1992;Fausel et al., 2014; Jain et al., 2013; Valles et al., 2005). Bouts of AD can arise multiple times daily due to the noxious yet unperceived afferent stimulation produced by normal, intermittent filling of the bladder and bowels (Fougere et al., 2016; Hubli et al., 2015; Popok et al., 2016). In light of this, it is perhaps not surprising that eliminating AD is one of the highest priorities of the SCI population, based on a large national survey (Anderson, 2004) which reported that both quadriplegics and paraplegics prioritize the recovery of bowel/bladder function and elimination of $\mathrm{AD}$ over regaining walking movements, highlighting the need for research strategies to mitigate the development of $\mathrm{AD}$ altogether.

In this review, we provide a clinical description of $\mathrm{AD}$ along with its pharmacological management, and discuss the underlying pathophysiological changes that contribute to such dangerous, episodic hypertension after high-level SCI. We further describe recent studies revealing body-wide disturbances that result from chronic recurring episodes of $\mathrm{AD}$, including vascular, cardiac and immunological dysfunctions. Contemporary research strategies will be considered to understand more comprehensively the underlying mechanisms, the full physiological impact of this syndrome that typically occurs multiple times daily, and potential therapeutic approaches to abrogate its development. 


\section{Clinical Description of AD}

\subsection{Who is at risk for developing $A D$ ?}

The T6 spinal segment is critical to the development of AD (Lindan et al., 1980;Mathias et al., 1988; Snow et al., 1978), as damage at or above this level interrupts descending modulation of the thoracolumbar SPN that regulate vasomotor tone, notably in the extensive splanchnic vascular bed (Blackmer, 2003; Gao et al., 2002). These vessels are innervated by the splanchnic nerves arising from the T5-T12 levels (Loukas et al., 2010) and receive approximately $25 \%$ of the cardiac output (Greenway et al., 1974; Rowell, 1990), which can have a large influence on total peripheral resistance and blood pressure. There are, however, uncommon reports of $\mathrm{AD}$ occurring after lesions below $\mathrm{T} 6$ but the magnitude of hypertension and changes in heart rate tend to be relatively mild since some degree of control over splanchnic sympathetic outflow remains intact (Moeller et al., 1973).

Not all individuals with SCI at or above the T6 level develop AD, with the prevalence reported between 48\% and 91\% (Curt et al., 1997; Lindan et al., 1980; Snow et al., 1978). This discrepancy is likely attributed to differences in the completeness of SCI, time elapsed since injury, and differences in the criteria used to confirm the presence of AD used among studies (Furusawa et al., 2011). Indeed, the clinical definition of AD is somewhat inconsistent (see section 2.2). Interestingly, $\mathrm{AD}$ has been documented in cases of nontraumatic abnormalities of the spinal cord such as intramedullary astrocytoma (Furlan et al., 2003) and multiple sclerosis (Kulcu et al., 2009), indicating that disruption of descending vasomotor pathways in any manner may contribute to the development of this syndrome.

\subsection{Characteristic features of $A D$}

The magnitude of hypertension required to be considered $\mathrm{AD}$ varies across studies. Snow et al. (1978) classified AD in adults as an increase of $40 \mathrm{mmHg}$ systolic blood pressure whereas Popok et al. (2016) defined AD as an increase of $20 \mathrm{mmHg}$ systolic blood pressure. Others (Lindan et al., 1980) diagnosed AD as a sudden rise in both systolic and diastolic blood pressure of any magnitude. Veteran's Affairs guidelines recommend that AD in adults is considered following abrupt elevation in systolic blood pressure of $20-40 \mathrm{mmHg}$ above baseline, whereas in pediatric SCI an increase of 15-20 mmHg systolic pressure warrants consideration (Canon et al., 2015; Consortium for Spinal Cord, 2002).

In addition to elevated blood pressure, individuals with an acute episode of AD can experience a diverse set of symptoms including debilitating headache, sweating, flushing of the skin above the injury level, piloerection, stuffy nose, blurred vision and anxiety (Karlsson, 1999). While these symptoms are not simultaneously present in all cases, headache and sweating above the lesion occurs $88 \%$ of the time (Lindan et al., 1980). Although the classical definition of $\mathrm{AD}$ is acute hypertension coincident with bradycardia (Erickson, 1980; Guttmann et al., 1947; Trop et al., 1991), the importance of heart rate in the diagnosis of AD is a matter of controversy. Lindan et al. (1980) reported an equal incidence of bradycardia and tachycardia (increase in heart rate) in documented cases of $\mathrm{AD}$, whereas others report that tachycardia is more common (Hickey et al., 2004; Kewalramani, 1980; Scott et al., 1978). Whether an episode of AD is concomitant with an increase or decrease in 
heart rate may depend on the injury level (Collins et al., 2006; Karlsson, 1999; Krassioukov et al., 2003). As suggested by Karlsson (1999), activation of sympathetic circuits in the spinal cord below a cervical injury may propagate rostrally towards cardiac-innervating SPN (i.e., T1-T4), explaining why tachycardia is frequently observed during AD. However, the correlation between injury level and the direction of heart rate change during episodes of $\mathrm{AD}$ has not been formally investigated.

\subsection{Temporal development of AD after injury}

AD most often presents in the chronic phase of SCI, with a majority of cases first occurring 3-6 months after injury in humans (Lindan et al., 1980). While it may also occur in earlier stages of injury, the incidence of early AD is relatively low, with only $5.7 \%$ of individuals with SCI above T6 having clinically documented AD within the first month post-injury (Krassioukov et al., 2003). Though uncommon, the manifestation of AD in the early stage of injury is significant considering that treatment of acute, high-level SCI often includes pressor agents to help combat the profound hypotension associated with such injuries (reviewed in Ploumis et al., 2010). In cases of acute AD occurring within days of injury, systolic blood pressure as high as $210 \mathrm{mmHg}$ has been reported (Silver, 2000), suggesting that concurrent vasopressor support may compound damage during episodic hypertension.

In experimental SCI, the development of telemetric monitoring techniques, along with the advent of computer algorithms capable of processing large amounts of hemodynamic data, have allowed for detailed analysis of the temporal development of AD in conscious animals (Laird et al., 2006; Mayorov et al., 2001; Rabchevsky et al., 2012; West et al., 2015). In both rats and mice with high-thoracic SCI, spontaneous AD triggered by naturally occurring stimuli emerges in a biphasic pattern with a transient surge of events occurring within the first week, followed by a gradual rise in frequency beginning around 2-weeks post-injury (Rabchevsky et al., 2012; West et al., 2015; Zhang et al., 2013). Moreover, the magnitude of change in systolic pressure during these events increases over time (West et al., 2015). These observations generally correspond to the development of $\mathrm{AD}$ in humans, where the initial disruption to descending vasomotor pathways allows for early AD (Krassioukov et al., 2003) before maladaptive changes in viscerosympathetic circuitry associated with more frequent and severe cases occur during the more chronic stages (West et al., 2015). Recent capabilities of screening ambulatory blood pressure recordings for daily AD events in humans (Hubli et al., 2014; Popok et al., 2016) will enable detailed analyses of the temporal progression of this syndrome in humans, as well as the efficacy of drugs to reduce the frequency or magnitude of recurrent $\mathrm{AD}$.

\section{Mechanisms contributing to AD}

\subsection{Loss of supraspinal control over sympathetic preganglionic neurons}

Within the intact nervous system, supraspinal vasomotor neurons residing in the paraventricular nucleus, rostral ventrolateral medulla, rostral ventromedial medulla, caudal raphe nuclei and A5 cell group (Calaresu et al., 1988; Chalmers et al., 1994; Hosoya et al., 1991; Jansen et al., 1995; Llewellyn-Smith, 2009; Strack et al., 1989; Sved et al., 2001) send projections to the intermediolateral cell column (IML), which is comprised of spinal nuclei 
containing sympathetic preganglionic neurons (SPN) that extends throughout the T1-L2 segments (Pyner et al., 1994; Tang et al., 1995; Zagon et al., 1993). These supraspinal neurons modulate the tonic firing of SPN which, in turn, send projections to the peripheral sympathetic chain ganglia or directly to the adrenal medulla (see Figure 1). The sympathetic ganglia act as the final sympathetic effector cells and innervate blood vessels throughout the body, whereas stimulation of the adrenal medulla secretes epinephrine and norepinephrine (NE) into the circulation. Together, this provides both direct and indirect control of blood vessel diameter and peripheral resistance to facilitate hemodynamic homeostasis (reviewed in Thomas, 2011).

After high-level SCI, the descending autonomic pathways responsible for supraspinal modulation of SPN become interrupted, reducing sympathetic tone below the injury (Stjernberg et al., 1986) and leaving SPN under the control of spinal influences alone. In the initial "spinal shock" phase of injury, which can last for weeks in humans (Ditunno et al., 2004), this loss of descending control manifests as significantly reduced blood pressure and depression of sympathetic reflexes (Frankel et al., 1972). Over time, however, plasticity of SPN and reorganization of spinal circuitry create a hyper-excitable state that contributes to the aberrant reflex activation of SPN in response to afferent stimulation (see Figure 1) (Krassioukov et al., 2002;Llewellyn-Smith et al., 2001; Rabchevsky, 2006). Because of the interruption to descending modulatory pathways, which would normally inhibit the SPN during hypertension via the baroreflex (Guyenet et al., 1981), AD persists until the stimulus is withdrawn.

\subsection{Synaptic reorganization of sympathetic preganglionic neurons (SPN)}

The damage to descending vasomotor pathways caused by SCI leaves many SPN partially denervated, causing a number of histological and functional changes in these neurons in both the human and rat (Krassioukov et al., 1999; Krassioukov et al., 1995; Krassioukov et al., 1996). Whereas SPN activity is normally regulated by a confluence of supraspinal and intraspinal inputs, their ongoing activity after complete SCI depends solely on the influence of spinal sympathetic interneurons (Schramm, 2006). Spinally derived sources of input to SPN include interneurons residing in laminae V, VII and X (Cabot et al., 1994; Cano et al., 2001; Clarke et al., 1998; Deuchars et al., 2001;Deuchars et al., 2015; Joshi et al., 1995; Tang et al., 2004a). While there are no direct synaptic inputs to SPN from primary afferents, it is thought that sensory neurons can influence the SPN via such spinal interneurons (Laskey et al., 1988; Schramm, 2006). The integration of supraspinal and intraspinal inputs on SPN is complex and involves both monosynaptic and polysynaptic pathways (reviewed in Deuchars et al., 2015).

After experimental T4 spinal cord transection in adult rats, profound morphological changes occur to SPN within the IML below the lesion. Within 3 days of injury, the dendritic length and diameter of SPN soma decrease dramatically in response to the degeneration of terminals with supraspinal origins (Llewellyn-Smith et al., 2001). By two-weeks, however, the somatic size and dendritic arbor of SPN appears normal again (Krassioukov et al., 1996; Krenz et al., 1998a). These dynamic changes in gross SPN morphology correspond temporally with the evolution of cardiovascular dysfunction in rats with high-level SCI, 
where pronounced resting hypotension occurs in the first days, followed by a gradual increase in basal blood pressure and the appearance of recurrent AD by two weeks postinjury (Laird et al., 2006; Mayorov et al., 2001; Rabchevsky et al., 2012; West et al., 2015).

While atrophied SPN regain a normal morphology in the weeks after injury, experimental evidence suggests that a radical reorganization of synaptic inputs controlling their activity occurs. Weaver et al. (1997) demonstrated altered expression patterns of GAP-43 (growth associated protein-43), a marker of reactive sprouting, in both mature axons and growth cones in close apposition to SPN caudal to a complete mid-thoracic transection weeks after injury. Because of the complete transection model used and absence of degenerating supraspinal axons in the IML after 7 days, the source of these GAP-43 immunoreactive axons was limited to spinal neurons below the injury, suggesting reorganization of intraspinal sympathetic circuits that may contribute to the exaggerated sympathetic reflex during an AD event. Llewellyn-Smith et al., (2001) also observed a switch in the ratio of synapses on SPN containing glutamate or $\gamma$-aminobutyric acid (GABA), indicating a shift in the balance of excitatory and inhibitory influences, respectively. Specifically, Transection caused a decrease in the percentage of glutamatergic inputs versus an increase in the percentage of GABAergic inputs on SPN in the IML at the T8 spinal level after two-weeks, implying a predominantly inhibitory synaptic integration. While this observation is consistent with the resting hypotension and reduced sympathetic outflow seen after SCI, how this relates to the intense sympathetic outbursts that occur in response to noxious visceral stimulation is uncertain. Recent work by Huang et al. (2016) indicates that complete high-thoracic (T2) spinal cord transection in rats causes GAB A neurotransmission to convert from an inhibitory to excitatory role in nociceptive circuits. While the influence of SCI on GABAergic regulation of SPNs was beyond the scope of this work, it provides evidence that GABAergic inputs onto SPN may provide excitatory drive after SCI (Rabchevsky, 2006).

An alternative explanation may be that glutamatergic synapses on SPN are the predominate input recruited by noxious visceral stimulation. It has been documented that glutamatergic signaling through both NMDA and AMPA receptors is important for the initiation of AD in response to noxious colorectal distension (CRD) (Maiorov et al., 1997). Ueno et al. (2016) recently demonstrated that chemogenetic silencing of Vglut $2^{+}$(vesicular glutamate transporter 2) interneurons after T3 SCI suppressed anti-inflammatory sympathetic reflexes related to $\mathrm{AD}$ (see section 5.2). This is further supported by studies testing the anti-epileptic and neuropathic pain medication gabapentin (GBP) as an experimental treatment for $\mathrm{AD}$ (Rabchevsky et al., 2011). GBP is known to inhibit pre-synaptic glutamate release by binding to the a251 subunit of voltage-gated calcium channels (Coderre et al., 2005; Coderre et al., 2007; Gee et al., 1996; Shimoyama et al., 2000) and has been shown to reduce both the magnitude and frequency of AD in rats with complete Transection, specifically after acute but not chronic administration (Rabchevsky et al., 2011; Rabchevsky et al., 2012). Notably, however, the site(s) of action and mechanism(s) through which GBP mitigates AD remains uncertain. It is feasible that GBP acts by reducing glutamatergic transmission at the level of both primary afferents entering the spinal cord as well as glutamatergic spinal interneurons synapsing with SPN. GBP has also been reported to inhibit excitatory synaptogenesis both in-vitro and in-vivo by blocking the binding of synaptogenic 
thrombospondin proteins to the a251 subunit (Eroglu et al., 2009). This suggests that GBP may work to reduce aberrant excitatory synapse formation in viscerosympathetic circuits after SCI. However, the short 2-3 hour half-life of GBP in rats (Radulovic et al., 1995; Vollmer et al., 1986) likely explains why once daily GBP treatment is insufficient to significantly reduce the frequency of spontaneous $\mathrm{AD}$ in the hours following administration; and likely insufficient to alter putative synaptic formation (Rabchevsky et al., 2012). Further studies into the synaptic mechanisms controlling SPN during noxious stimulation, as well as the precise means through which GBP mitigates AD may help identify novel therapeutic targets for prophylactically preventing the development of this syndrome.

\subsection{Primary afferent sprouting}

Intraspinal sprouting of primary afferent nociceptive fibers is also thought to contribute to the development of AD. After experimental SCI, the central arbors of unmyelinated c-fiber afferents expressing calcitonin gene-related peptide (CGRP), a marker of nociceptive fibers, sprout into the dorsal horn caudal to the injury (Hou et al., 2009; Krenz et al., 1998b). The extent of $\mathrm{CGRP}^{+}$fiber sprouting into the lumbosacral spinal cord correlates with the magnitude of AD elicited by noxious CRD (Cameron et al., 2006; Krenz et al., 1999), suggesting that enhanced sprouting of nociceptive fibers increases reflex activation of SPN through propriospinal "relay" neurons (Figure 1, see section 3.4). Increased CGRP' fiber density becomes apparent two weeks after experimental injury (Hou et al., 2009; Krenz et al., 1998b), a time at which AD develops reliably in spinal rats (Krassioukov et al., 1995; Laird et al., 2006). Importantly, increased CGRP ${ }^{+}$fiber sprouting in the dorsal horn is also seen in the chronic stages of human SCI, and in one case has been associated with a welldocumented history of AD (Ackery et al., 2007).

The sprouting of c-fibers appears to be primarily dependent on nerve growth factor (NGF) signaling. After transection or contusion SCI, resident neurons and glia upregulate the expression of intraspinal NGF rostral and caudal to the lesion (Bakhit et al., 1991; Brown et al., 2004). Blockade of NGF signaling through intrathecal delivery of anti-NGF antibodies for two-weeks after T4-transection SCI effectively mitigates injury-induced sprouting of $\mathrm{CGRP}^{+}$fibers throughout the spinal cord. Furthermore, animals receiving anti-NGF therapy had less severe AD in response to noxious CRD (Krenz et al., 1999), although this treatment did not abolish it completely. Cameron et al. (2006) used a proof-of-principle approach to overexpress NGF in the cord after T4-transection using adenovirus injections into either the T13/L1 or L6/S1 spinal levels innervating the distal colon and found that the pressor and bradycardic responses to CRD were significantly exacerbated. Conversely, injured cords injected with adenovirus encoding semaphorin $3 \mathrm{a}$, a specific chemorepellant for both cfibers and sympathetic fibers (Tang et al., 2004b), had significantly diminished pressor and bradycardic responses during CRD. Such exacerbations or ameliorations were significantly correlated with increased or decreased $\mathrm{CGRP}^{+}$fiber sprouting, respectively.

\subsection{Propriospinal plasticity}

Plasticity of ascending lumbosacral propriospinal fibers that relay pelvic sensory information rostrally towards SPN in the thoracic cord is also thought to contribute to the development of AD. There is compelling evidence for functional plasticity of propriospinal 
interneurons which comprise spinal sympathetic circuits after transection SCI in the rat. Krassioukov et al. (2002) investigated the response of sympathetically-correlated interneurons to both noxious and innocuous stimuli hours following T3 transection (acute) as well as after one month (chronic). In the chronic but not acute stage of injury, interneurons whose electrical activity was cross-correlated with that of simultaneously recorded renal sympathetic nerve activity were excited by noxious CRD and cutaneous pinching, as well as non-noxious brushing of the skin caudal to the injury. This seminal study showed that in the weeks after injury, plasticity occurs within somatosensory relay neurons that influence the activity of SPN.

This electrophysiological evidence was supported histologically following anterograde tracer injections into the lumbosacral cord after complete T4-transection which significantly increased labeling of ascending propriospinal fibers originating in the dorsal gray commissure (DGC), notably found in juxtaposition to thoracic SPN labeled with Fluorogold (Hou et al., 2008). The DGC is a region in which pelvic visceral afferents terminate and send relay projections rostrally toward supraspinal targets (Al-Chaer et al., 1996; Hosoya et al., 1994; Matsushita, 1998; Pascual et al., 1993; Vizzard, 2000). Hou et al. (2008) found that a single session of prolonged, intermittent CRD performed two weeks after injury caused enhanced neuronal activation throughout the lumbosacral DGC, as indicated by increased expression of the immediate early gene $c$-fos in comparison to sham animals in which intact descending modulation prevents such expression. It remains unclear, however, whether the DGC neurons project directly to SPN or whether they project to excitatory interneurons to indirectly modulate the excitability of SPN (Rabchevsky, 2006).

Collectively, these findings support a model of AD in which plasticity of ascending propriospinal fibers, in conjunction with sprouting of primary afferents, creates an amplification of afferent stimuli below the injury such that noxious inputs are more likely to activate SPN to initiate unmodulated sympathetic reflexes resulting in an episode of AD (Figure 1). Previous technical limitations made it difficult to directly test the neuroanatomical basis of the AD reflex in live animals. However, with the recent development of elegant genetic and chemogenetic silencing techniques (Kinoshita et al., 2012; Stachniak et al., 2014; Zhu et al., 2014), it may now be feasible to directly assess the role of specific populations of ascending propriospinal neurons in conveying lumbosacral afferent input to rostral segments containing cardiovascular SPN (Figure 1, see section 6).

\subsection{Peripheral adrenergic hypersensitivity}

In addition to maladaptive plasticity of viscerosympathetic circuitry, there is also evidence of peripheral changes responsible for the exaggerated pressor response to afferent stimulation. In quadriplegics, resting blood pressure and plasma catecholamine levels are both significantly lower than in intact subjects (Mathias et al., 1976). This is consistent with the observation that sympathetic outflow below the lesion is lower both acutely and chronically after SCI (Mathias et al., 1979; Wallin et al., 1984), which would be expected to produce lower concentrations of circulating catecholamines (Goldstein et al., 1983). However, it has been demonstrated that the vasomotor response to intravenously infused NE is enhanced in quadriplegics with a documented history of AD. Specifically, by measuring the diameter of 
the dorsal foot vein before and after local intravenous administration of NE, Arnold et al. (1995) found that the concentration of NE required to induce a 50\% reduction in resting vessel diameter was significantly lower in tetraplegics compared to normal controls (1.6 $\mathrm{mg} / \mathrm{min}$ vs. $10.9 \mathrm{ng} / \mathrm{min}$ ). Similarly, Krum et al. (1992b) found that the dose of intravenously infused phenylephrine (a peripheral a 1-adrenergic receptor agonist) required to produce a pressor response of $20 \mathrm{mmHg}$ is significantly lower in functionally complete quadriplegics compared to normal individuals. Furthermore, Krum et al. (1992a) reported that even modest increases in plasma NE during bladder cystometry after high-level SCI were sufficient to produce a significant pressor response greater than $20 \mathrm{mmHg}$ systolic. Taken together, these studies indicate that SCI promotes hypersensitivity of the vasculature to catecholamines released through aberrant, unmodulated sympathetic reflexes, and that this hypersensitization may contribute to the severity of episodic hypertension after SCI.

There is indication that peripheral sensitization following SCI is limited to the vasculature caudal to the lesion and not within rostral vascular beds in which central sympathetic control remains intact. Following T4 transection in rats, Rummery et al. (2010) found evidence of enhanced neurovascular transmission in the saphenous artery which receives sympathetic outflow from the lower thoracolumbar cord. However, SCI-related neurovascular potentiation was not seen in the median artery which receives sympathetic outflow from the cord rostral to the lesion. Brock et al. (2006) similarly found that T4 transection in rats leads to increased neurovascular transmission within the mesenteric vasculature, with perivascular nerve stimulation producing five-fold increased contractions of mesenteric arteries seven weeks after SCI. This increased reactivity of mesenteric arteries was blunted by the adrenergic antagonist prazosin, further implicating that peripheral hypersensitization is secondary to changes in adrenergic transmission after injury. While the mechanism of this phenomenon is not fully known, Brock et al. (2006) suggest that decreased norepinephrine reuptake may be a contributing factor. Alternatively, Al Dera et al. (2012) report that complete SCI in rats also alters L-type calcium channels, with their activation playing a larger role in smooth muscle contraction of tail arteries isolated after injury. Whether or not these two mechanisms are unique to specific vascular beds caudal to the lesion remains unclear.

Consistent with the hypothesis that SCI causes enhanced adrenergic sensitivity in peripheral vasculature, Lee et al. (2016) demonstrated increased protein expression of the a1adrenergic receptor in the femoral artery of rats after T10 spinal contusion. Furthermore, this increased receptor expression corresponded to an enhanced pressor response and vasoconstriction of isolated femoral arteries in response to phenylephrine stimulation. Whether or not the time-course of these changes corresponds to the timeline over which AD develops in rodents or humans remains unknown. Moreover, it is unclear whether these findings are applicable to AD since this syndrome does not develop after T10 contusion SCI. Although there is compelling evidence that peripheral sensitization is important in the pathophysiology of $\mathrm{AD}$, many questions remain regarding the underlying cellular processes and time-course over which adrenergic hyper-responsiveness develops, as well as the relative contribution compared to central maladaptive plasticity discussed. 


\section{Clinical management of AD}

A variety of non-pharmacological and pharmacological strategies can be used to treat $\mathrm{AD}$. Since AD often resolves once the inciting stimulus is removed, the current standard of care recommends identifying and eliminating the inciting factors, when possible, before pharmacological approaches are considered (Consortium for Spinal Cord, 2002). Immediate measures involve assessment of resting arterial pressure and monitoring for other symptoms associated with $\mathrm{AD}$ (see section 2.2). If hypertension is observed, it is advised to move patients into an upright position to facilitate the lowering of arterial pressure through hydrostatic redistribution of blood to the lower extremities. This postural maneuver causes a reduction of blood pressure in high-level SCI patients (Krassioukov et al., 2006), although the efficacy to alleviate hypertension specifically during $\mathrm{AD}$ has not yet been formally investigated (Krassioukov et al., 2009). Since filling of the bladder and impaction of the bowel are the most common triggers of AD (Lindan et al., 1980), bladder voiding or bowel care routines should next be considered along with a general inspection for other possible sources of noxious stimulation such as pressure sores, tight clothing and skin laceration. Given that blood pressure can fluctuate rapidly in patients with AD, it is important to monitor blood pressure every 2-5 minutes for resolution or exacerbation of hypertension during physical examination (Consortium for Spinal Cord, 2002).

While some cases of $\mathrm{AD}$ are mild and resolve relatively easily, more severe cases can produce profound levels of hypertension and have no readily identifiable cause.

Furthermore, it may be difficult to identify and remove the triggering stimuli, particularly for individuals with high thoracic and cervical injuries who have limited dexterity and mobility. Therefore, a variety of drugs and medical procedures have been employed for the control of $\mathrm{AD}$, primarily through managing hypertension. Some of the most common remedies are briefly discussed below.

\subsection{Nitrates}

Organic nitrates, such as nitroglycerine paste, are currently the most commonly prescribed medications for mitigating acute episodes of AD (Braddom et al., 1991; Caruso et al., 2015). Nitrates are a class of drugs that are converted to or release nitric oxide (NO), an endogenous molecule that induces smooth muscle relaxation in the vasculature (Moncada et al., 1993). For acute episodes of $\mathrm{AD}$, it is recommended to apply $2 \%$ nitroglycerin paste onto the skin above the level of SCI (Braddom et al., 1991). Vasodilation and subsequent reduction of blood pressure occurs rapidly after transdermal application and the paste can be wiped off once the therapeutic effect has been achieved (Grobecker, 1990). Moreover, a variety of oral and transdermal patch preparations are available and easy for patients and caregivers to administer. In severe cases of AD that are difficult to control, notably in a clinical setting, intravenous sodium nitroprusside may also be used to rapidly resolve hypertension (Valles et al., 2005).

\subsection{Nifedipine}

Nifedipine is an L-type calcium $\left(\mathrm{Ca}^{2+}\right)$ channel blocker that reduces the influx of $\mathrm{Ca}^{2+}$ into vascular smooth muscle cells, leading to a reduction in peripheral resistance and 
consequently blood pressure. Despite few controlled clinical trials, nifedipine has been widely used to treat AD in SCI patients (Braddom et al., 1991; Caruso et al., 2015; Dykstra et al., 1987; Esmail et al., 2002; Krassioukov et al., 2009; Thyberg et al., 1994). In a survey of clinicians with extensive experience treating AD, Braddom et al., 1991) found that nifedipine was the most commonly prescribed agent to manage minor or severe symptoms of AD. More recently, nitrates have become slightly more prominent than nifedipine in treating minor or severe episodes of AD (Caruso et al., 2015), likely stemming from safety concerns regarding the use of nifedipine during hypertensive crises because it may overshoot the therapeutic drop in blood pressure and cause severe hypotension and ischemia (Chobanian et al., 2003). Although there are no formal descriptions in the literature of adverse effects related to the use of nifedipine specifically for $\mathrm{AD}$, it is possible that it may reduce arterial pressure below the range for critical renal, cerebral and cardiac vascular beds to autoregulate their perfusion, particularly since many with $\mathrm{AD}$ are predisposed to resting and orthostatic hypotension (Furlan et al., 2008).

\subsection{Prazosin}

The adrenergic receptor antagonist, prazosin, is another drug used to treat AD (Krum et al., 1992c; Phillips et al., 2015). Prazosin is an antihypertensive agent that works by specifically blocking a 1-adrenergic receptors located on peripheral vasculature (Cavero et al., 1980). Unlike other hypertension medications, prazosin has little effect on cardiac function or resting blood pressure (Jaillon, 1980), making it safer to use in patients with chronic hypotension. Krum et al. (1992c) reported that, compared to placebo treatment, twice daily prazosin significantly decreased the magnitude of hypertension and severity of secondary symptoms during AD caused by a variety of genitourinary and colorectal stimuli. More recently, Phillips et al. (2015) reported that prazosin reduced the magnitude of hypertension during $\mathrm{AD}$ during sperm retrieval procedures involving penile vibrostimulation, which is a well-documented cause of AD. Collectively, research on the use of prazosin indicates that it may be useful as a prophylactic treatment for AD triggered by a variety of iatrogenic stimuli (Krum et al., 1992c; Phillips et al., 2015) .

\subsection{Botulinum Toxin}

Conservative pharmacological approaches are not always effective, and some individuals require more aggressive treatments (Krassioukov et al., 2009). One such treatment is botulinum toxin (BTX), a neurotoxin derived from Clostridium botulinum that suppresses neuromuscular transmission by cleaving synaptic proteins required for neurotransmitter exocytosis (reviewed in Dolly, 2003). Due to its ability to temporarily cause detrusor muscle paralysis by preventing parasympathetic post-ganglionic acetylcholine release, delivery of BTX into the detrusor muscle has been used to treat bladder dysfunction secondary to SCI, such as neurogenic detrusor overactivity (NDO) (Dykstra, 2003; Dykstra et al., 1988; Orasanu et al., 2013; Schurch et al., 2005). As these conditions disrupt normal micturition and can lead to noxious distension of the bladder, they are associated with the occurrence of AD. While there have been no large-scale clinical trials for BTX as a prophylactic treatment of $\mathrm{AD}$, there is indication that this could be a safe and tenable approach to minimize $\mathrm{AD}$ associated with bladder dysfunction and certain medical procedures such as cystoscopy. Schurch et al. (2000) reported a disappearance of AD caused by bladder voiding in a small 
subset of patients receiving BTX injections into the detrusor muscle to treat neurogenic bladder, though the duration of this improvement was not specified. Recently, Fougere et al. (2016) conducted a small clinical trial specifically to assess the efficacy of intradetrusor injections of BTX to reduce bladder-related AD and observed a decrease in the severity of $\mathrm{AD}$ during cystometric filling of the bladder. Moreover, ambulatory blood pressure recordings revealed a decrease in the frequency of daily bladder-related $\mathrm{AD}$ for at least one month, accompanied by an increase in quality of life measures. Such reports indicate that BTX treatment may be a safe and potentially long-lasting means of prophylactically treating bladder-related AD. Notably, the duration of effect after BTX treatment is limited due to a combination of compensatory sprouting of peripheral nerve terminals and the gradual recovery of synaptic proteins necessary for neurotransmitter release (Dolly, 2003). While the duration of detrusor paresis is approximately 9 months (Schurch et al., 1996), it remains unknown how long intradetrusor BTX treatment can provide relief of AD.

In addition to temporary paralysis of bladder smooth muscle, there is also evidence that BTX treatment reduces AD by modulating sensory transmission into the spinal cord. Apostolidis et al. (2005) reported that intradetrusor injections of BTX in patients with NDO caused a decrease in the expression of both purinoceptors $\left(\mathrm{P}_{2} \mathrm{X}_{3}\right)$ and capsaicin receptors (TRPV1) in sensory fibers innervating the bladder, and that this decrease was correlated temporally with a significant improvement in bladder function. These receptors are involved in bladder nociception (Birder et al., 2002; Cockayne et al., 2000), suggesting that decreased afferent signaling contributes to the improvement in urodynamic function after BTX treatment. In an experimental model, Elkelini et al. (2012) instilled BTX into the bladder of rats after T4-transection and observed a significant reduction in the magnitude of $\mathrm{AD}$ induced by bladder distension during cystometry, which was associated with reduced NGF expression in the bladder and sensory neurons in the dorsal root ganglia. As NGF regulates c-fiber density in the bladder (Schnegelsberg et al., 2010), it is also possible that BTX reduces bladder-related $\mathrm{AD}$ by decreasing the innervation or distribution of nociceptive fibers. Notably, intradetrusor BTX treatment has also been used to alleviate refractory AD in a pediatric SCI patient (Lockwood et al., 2016).

\section{Systemic effects of recurrent AD}

\subsection{Cardiovascular Changes}

Emerging evidence suggests that the recurrence of $\mathrm{AD}$, which can occur more than 40 times a day for some individuals (Hubli et al., 2015), adversely affects multiple physiological systems over time. Alan et al. (2010) demonstrated that repeated instances of AD after experimental SCI exacerbate injury-induced peripheral vascular dysfunction. Isolated mesenteric arteries from rats which underwent 30-minutes of continuous CRD daily for twoweeks after T3 transection SCI had a more pronounced vasoconstrictor response to phenylephrine (an a 1-adrenergic agonist) compared to arteries from animals with SCI only. This suggests that injury-induced adrenergic hypersensitization, which itself is a mechanism involved in the etiology of $\mathrm{AD}$ (see section 3.5), is exacerbated by repeated instances of $\mathrm{AD}$ and may help explain why the severity of AD increases over time (West et al., 2015). If this is the case, it should be possible to dampen the temporal increase in AD severity by 
pharmacologically controlling adrenergic hypersensitization. However, as discussed in section 3.5, the cellular processes leading to adrenergic hyper-responsiveness have yet to be elucidated.

Repetitive surges in blood pressure from recurrent $\mathrm{AD}$ may also induce maladaptive structural changes in peripheral vasculature (West et al. (2013). Vascular remodeling is a dynamic process that responds to changes in shear stress from normal hemodynamic fluctuations as well as hypertensive disease (Baeyens et al., 2015; Schiffrin, 2004; Silver et al., 2006). While SCI alone is associated with changes in vascular structure, this is believed to be an adaptation to the decreased metabolic demands of atrophied tissue below the injury (Olive et al., 2003). The hypothesis that blood pressure fluctuations from recurrent AD cause further remodeling of peripheral vasculature requires additional study, particularly since structural changes to resistance vessels, such as alterations in the ratio of wall thickness/ lumen diameter, are strongly associated with cardiovascular disease (Rizzoni et al., 2003).

Deleterious changes in cardiac function are also associated with daily repeated bouts of experimental AD. West et al. (2016) investigated the effects of recurrent AD on cardiac structure and function in rats following T3 transection. Beginning 2-weeks after injury, rats received 60-minutes of repetitive CRD daily for 4 weeks. In-vivo echocardiography revealed that animals with daily induced AD (SCI-AD) had diminished basal contractility and their hearts developed significantly lower left ventricular pressure with a slower rate of ventricular contraction. These alterations in cardiac mechanics were accompanied by a dampened inotropic response to $\beta$-adrenergic stimulation during isoproterenol challenge in the SCI-AD group compared to $\mathrm{SCI}$ alone, despite no differences in $\beta$-adrenergic receptor expression. Taken together, this data suggests that recurrent $\mathrm{AD}$ leads to aberrant cardiac mechanics, which may be due to desensitization of adrenergic receptors in the heart. Notably, these experimental findings were corroborated with clinical data which indicated a relationship between the number of daily AD events and impaired cardiac mechanics in a small sample of humans with mid-cervical SCI (C4-C8). As suggested by the authors (West et al., 2016), this consequence of recurrent $\mathrm{AD}$ may also contribute to the increased risk of cardiovascular disease in people with SCI (Cragg et al., 2013; Garshick et al., 2005).

In addition to peripheral vasculature, there are emerging reports of associations between $\mathrm{AD}$ and cerebrovascular function. Phillips et al. (2016b) found that high-thoracic SCI in rats causes maladaptive changes in middle cerebral artery (MCA) structure and function. Seven weeks after T3 transection, ex-vivo analysis of MCA revealed decreased vessel compliance and diminished vascular reactivity to vasoconstrictive 5-hydroxytryptamine. The functional changes in MCA preparations were seen in conjunction with increased collagen deposition and wall thickness, suggesting that arterial stiffening and structural remodeling after SCI may impair cerebral autoregulation. Considering that $\mathrm{T} 3$ transection in rats reliably causes $\mathrm{AD}$ to develop within two weeks, and given the seven-week duration of this study, it is likely that recurrent $\mathrm{AD}$ contributed to these findings. Potential changes in cerebrovascular function may help explain cognitive dysfunction which has been documented after highlevel SCI (Davidoff et al., 1990; Phillips et al., 2014; Wecht et al., 2013). Phillips et al. (2016a) provided preliminary data suggesting that cerebral autoregulation is capable of maintaining sufficient blood flow to the brain during mild and slowly evolving episodes of 
$\mathrm{AD}$, though it remains unknown if the cerebral vasculature can respond appropriately during more severe and rapidly occurring episodes. Ultimately, it will be important for future studies to determine whether recurrent AD causes structural and functional modifications to peripheral and cerebral vasculature since these maladaptations have been proposed to contribute to cardiovascular and cognitive dysfunction after SCI (Phillips et al., 2016b; Wecht et al., 2013).

\subsection{Immunomodulatory effects of AD}

In addition to cardiovascular anomalies, $\mathrm{AD}$ is linked to aberrant functioning of the immune system (Ueno et al., 2016; Zhang et al., 2013). Compared to the general population, people with chronic SCI have a weakened immune system capacity (Campagnolo et al., 1994; Iversen et al., 2000) and are more susceptible to lethal infections such as pneumonia (Brommer et al., 2016). This phenomenon, known as spinal cord injury-induced immune depression syndrome (SCI-IDS) (Riegger et al., 2007), is dependent on the level of SCI, with injuries above the level of the major sympathetic outflow being associated with more severe immunosuppression (Brommer et al., 2016; Campagnolo et al., 1997; Iversen et al., 2000; Lucin et al., 2007; Zhang et al., 2013). Iversen et al. (2000) collected blood and bone marrow samples from individuals with SCI and observed diminished lymphocyte activity and impaired proliferation of hematopoietic progenitor cells, particularly in tetraplegics with mid-cervical injuries. Similarly, Lucin et al. (2007) found that T3 but not T9 transection in mice causes a loss of splenocytes and B cells in association with enhanced levels of splenic $\mathrm{NE}$ and blood cortisol levels.

In intact subjects, the immune system is modulated by the hypothalamic-pituitary-adrenal axis (HPA) and sympathetic nervous system (SNS) (reviewed in Irwin et al., 2011). In response to physical or psychological stress, the anterior pituitary gland releases adrenocorticotropic hormone to stimulate the release of glucocorticoids (GCs) from the adrenal cortex into the blood. There is also evidence for direct neural innervation of the adrenal cortex by SPN (Engeland et al., 2005), suggesting that sympathetic activity during AD may also promote GC release. GCs subsequently bind to the intracellular glucocorticoid receptor in leukocytes to alter the transcriptional programming and limit inflammatory responses (reviewed in Rhen et al., 2005). Additionally, activation of the SNS modulates the immune system through the release of NE directly into lymphoid tissues, where it binds to $\beta_{2}$-adrenergic receptors on a variety of immune cells, including lymphocytes and macrophages. Like GCs, NE can have immunosuppressive effects on a variety of immune cells, including B and T lymphocytes, by activating intracellular signaling cascades such as the cyclic adenosine monophosphate (cAMP) pathway. Ultimately, the result of such stimulation is to shunt cellular activity away from a pro-inflammatory state (reviewed in Lorton et al., 2015).

Because of the immunosuppressive role of SNS stimulation, it is thought that SCI-IDS is caused by heightened sympathetic activity and catecholamine release during recurrent bouts of AD. Zhang et al. (2013) reported a causal link between AD and chronic immunosuppression. The temporal development of $\mathrm{AD}$ in mice with $\mathrm{T} 3$ transection SCI corresponded to an elevated level of circulating GCs and accumulation of NE within the 
spleen, along with a profound loss of greater than $50 \%$ of splenic leukocytes by 5-weeks post-injury. Compared to sham operated or low thoracic (T9) SCI mice which do not develop $\mathrm{AD}$, those with spontaneously occurring $\mathrm{AD}$ measured telemetrically and quantified with a computer detection algorithm had a limited capacity to produce antibodies after injection of immunogenic ovalbumin. Additionally, this immunodeficiency was exacerbated by experimentally inducing $\mathrm{AD}$ with repeated bouts of noxious $\mathrm{CRD}$. The immunosuppressive effects associated with established $\mathrm{AD}$ were reversed after treating injured mice with a cocktail of a selective $\beta_{2}$-adrenergic receptor antagonist and a GC receptor antagonist, concluding that immunosuppression after T3 SCI in mice is caused by AD-related elevations in NE and GC. Notably, however, this treatment cocktail was not reported to alter the occurrence of AD. These experimental findings in mice were corroborated with data from a mid-cervical SCI patient showing that tapping of the abdomen overlying the urinary bladder, which stimulated an episode of AD, caused an increase in catecholamine release with a concomitant reduction in lymphocyte proliferation (Zhang et al., 2013). More recently, Ueno et al. (2016) used an inducible chemogenetic silencing approach in mice with T3 SCI to inhibit glutamatergic interneurons thought to facilitate reflex activation of SPN innervating the spleen during AD. After silencing these neurons daily for 2-weeks, the quantity of splenic B and T cells was restored to pre-injury levels. Together, these studies may explain why people with high-level SCI, many of whom experience $\mathrm{AD}$, have increased susceptibility to a variety of infectious diseases, and further implies that controlling or preventing $\mathrm{AD}$ is essential for overall well-being.

Importantly, the immunomodulatory effects of recurrent $\mathrm{AD}$ may only be a contributing factor to SCI-IDS rather than the primary driver. For example, direct sympathetic innervation of the bone marrow (Bjurholm et al., 1988; Denes et al., 2005) is thought to help regulate hematopoiesis and immune function in the normal, uninjured state (reviewed in Jung et al., 2017). Therefore, dysregulated activity of decentralized sympathetic fibers innervating bone marrow following SCI may also contribute to SCI-IDS. Moreover, it is well documented that SCI leads to decreased bone density as a result of diminished gravitational load (Biering-Sorensen et al., 1990; Zehnder et al., 2004). As the bone marrow is a major site of hematopoiesis, it is possible that bone atrophy after SCI compromises the hematopoietic niche, which may help to explain the reduced immune cell production seen after injury (Iversen et al., 2000). The relative contribution of these potential mechanisms warrants future investigation.

\section{Emerging research strategies}

Important questions remain regarding the underlying mechanisms responsible for episodic $\mathrm{AD}$ that develops after SCI. While strong correlative evidence supports a role in maladaptive plasticity of lumbosacral primary afferents and ascending propriospinal neurons, the relative contribution of these modified pathways to the AD syndrome is unclear. Recently developed genetic and chemogenetic neuronal silencing techniques should allow future investigations aimed at dissecting the precise role of these distinct neuroanatomical pathways. For example, Kinoshita et al. (2012) injected a complimentary set of viral vectors into regions of the spinal cord containing the terminals and soma of propriospinal neurons thought to be critical for the execution of dexterous hand movements. In their model, a highly efficient 
retrogradely transported lentiviral vector carrying enhanced tetanus toxin (HiRET-eTeNT) under the control of the tetracycline-responsive element was injected into the spinal segments containing the terminals of their target neurons. In addition, a second adenoassociated viral (AAV) vector carrying a reverse tetracycline transactivation sequence (AAVrtTAV) was injected into the spinal cord segment containing the cell bodies of those same neurons. With this approach, it was possible to silence neurons by inducing the expression of tetanus toxin through systemic delivery of doxycycline. Notably, only the neurons which were doubly infected with both HiRET-eTeNT and AAV-rtTAV were silenced, providing a reversible and spatially targeted method for investigating the role of specific neural pathways. Based on such an approach, it is potentially feasible to doubly infect and silence ascending propriospinal relay neurons which originate in the lumbosacral cord that project rostrally towards thoracic SPN to directly test their contribution to AD induced through stimulation of lumbosacral afferents (see Figure 1). As discussed in section 5.2, Ueno et al. (2016) employed a novel chemogenetic silencing approach to prevent the development of SCI-IDS associated with AD by blocking neurotransmission of glutamatergic spinal interneurons, though it is unknown whether this approach would also ameliorate hemodynamic changes during AD. Moreover, this method silenced all glutamatergic interneurons in the injected regions (T5-T7) and, therefore, does not allow for the precise dissection of specific intraspinal pathways.

Alternatively, a recent report by Iyer et al. (2016) demonstrated the ability to silence specific nociceptive primary afferents using a chemogenetic method in which AAV carrying the engineered inhibitory hMD4(Gi) DREADD receptor (designer receptor exclusively activated by a designer drug) was injected directly into the sciatic nerve. Upon activation with the highly specific ligand clozapine-n-oxide (CNO), the hMD4(Gi) receptor hyperpolarizes neurons through induction of the G-protein inward-rectifying potassium channel (Armbruster et al., 2007). They demonstrated that intraperitoneal injection of clozapine-noxide (CNO) significantly increased mechanical and thermal nociceptive thresholds in the foot pads of animals with DREADD infected afferents. Because the genetic and chemogenetic silencing methods discussed here have distinct ligand-receptor interactions, it may be possible within a single animal to serially silence propriospinal relay neurons and primary afferents to directly investigate their contributions to both spontaneous and CRDinduced AD.

In addition to further mechanistic studies, it will also be important to fully elucidate the systemic effects of recurrent $\mathrm{AD}$. The metabolic consequences of sporadic, uncontrolled fluctuations in catecholamines and GCs released during AD are not well known. As suggested by Karlsson (1999), frequent daily bouts of AD accompanied with such abnormal surges in GCs and catecholamines may contribute to the high reported incidence of metabolic abnormalities in persons with SCI (Duckworth et al., 1980; Gorgey et al., 2014; Maruyama et al., 2008; Yekutiel et al., 1989). Considering that GC and catecholamines have a number of effects on energy metabolism in various tissues throughout the body, including the liver, spleen, pancreas, adipose tissue and skeletal muscle (reviewed in Barth et al., 2007; Vegiopoulos et al., 2007), it is possible that recurring AD predisposes or exacerbates the development of metabolic disease, such as insulin resistance and dyslipidemia. In support of this, Bluvshtein et al. (2011) reported that postprandial insulin resistance is present in 
tetraplegics with cervical SCI, but not in paraplegics with thoracic SCI that preserves some level of supraspinal control over sympathetic outflow. Moreover, manual percussion of the abdomen overlying the bladder in people with high-thoracic or cervical SCI was found to activate lipolysis in tissues below the injury level in association with increased blood pressure and catecholamine release (Karlsson et al., 1997). Whether a relationship exists between the magnitude and frequency of $\mathrm{AD}$ and the incidence of insulin resistance or abnormal lipid metabolism has not yet been formally investigated.

\title{
7. Conclusions
}

$\mathrm{AD}$ can have a significant impact on the quality of daily living and, if not treated properly and timely, this hypertensive syndrome can have deleterious cardiophysiological and systemic consequences. The most common treatment paradigms involve vasoactive drugs intended to resolve the acute hypertensive crises rather than preventing them from occurring, though some evidence suggests that prazosin and botulinum toxin may provide prophylactic management of $\mathrm{AD}$ associated with normal and iatrogenic urogenital stimulation. While well documented, the intracellular signaling processes underlying adrenergic hypersensitization in the context of $\mathrm{AD}$ are unknown. Recent methodological advances should allow for more detailed investigation into the relative contribution of specific propriospinal neurons and primary afferent fibers to this aberrant viscerosympathetic reflex after SCI. The widespread physiological consequences of recurrent $\mathrm{AD}$, which can happen dozens of times daily, have only recently been investigated. Animal models and clinical data indicate that repeated episodes of $\mathrm{AD}$ exacerbate peripheral adrenergic hypersensitization, suppress immune function, compromise cardiac mechanics, and potentially alter cerebrovascular and cognitive function. However, the potential effects of recurrent AD on peripheral and central vasculature structure, as well as widespread metabolism have only begun to be investigated. In light of recent data describing profound systemic effects of chronic $\mathrm{AD}$, it is increasingly important to develop more targeted therapies capable of preventing the development of this syndrome and its associated maladies altogether in order to improve quality of lives for individuals with SCI who are predisposed to this syndrome.

\section{Acknowledgments}

Funding

This work was supported by SCoBIRC Chair Endowment (AGR), 5 T32 NS077889 (KCE)

\section{Glossary of acronyms}

\author{
SCI spinal cord injury \\ AD autonomic dysreflexia \\ SCI-IDS spinal cord injury-induced immune depression syndrome \\ SPN sympathetic preganglionic neurons \\ IML intermediolateral cell column
}




$\begin{array}{ll}\text { NE } & \text { norepinephrine } \\ \text { BTX } & \text { botulinum toxin } \\ \text { NDO } & \text { neurogenic detrusor overactivity } \\ \text { NGF } & \text { nerve growth factor } \\ \text { GABA } & \text { gamma-aminobutyric acid } \\ \text { GBP } & \text { gabapentin } \\ \text { CRD } & \text { colorectal distension } \\ \text { SNS } & \text { sympathetic nervous system } \\ \text { HPA } & \text { hypothalamic pituitary axis } \\ \text { GC } & \text { glucocorticoid } \\ \text { DREADD } & \text { designer receptor exclusively activated by designer drug } \\ \text { CNO } & \text { clozapine-n-oxide } \\ \text { DGC } & \text { dorsal gray commissure } \\ \text { CGRP } & \text { calcitonin gene related peptide } \\ \text { NMDA } & \text { N-methyl-D-aspartate receptor } \\ \text { AMPA } & \text { a-amino-3-hydroxy-5-methyl-4-isoxazolepropionic acid receptor }\end{array}$

\section{References}

Ackery AD, Norenberg MD, Krassioukov A. Calcitonin gene-related peptide immunoreactivity in chronic human spinal cord injury. Spinal cord. 2007; 45:678-686. [PubMed: 17339890]

Al Dera H, Habgood MD, Furness JB, Brock JA. Prominent contribution of L-type Ca2+ channels to cutaneous neurovascular transmission that is revealed after spinal cord injury augments vasoconstriction. Am J Physiol Heart Circ Physiol. 2012; 302:H752-762. [PubMed: 22081708]

Al-Chaer ED, Lawand NB, Westlund KN, Willis WD. Pelvic visceral input into the nucleus gracilis is largely mediated by the postsynaptic dorsal column pathway. J Neurophysiol. 1996; 76:2675-2690. [PubMed: 8899637]

Alan N, Ramer LM, Inskip JA, Golbidi S, Ramer MS, Laher I, Krassioukov AV. Recurrent autonomic dysreflexia exacerbates vascular dysfunction after spinal cord injury. Spine J. 2010; 10:1108-1117. [PubMed: 21094471]

Anderson KD. Targeting recovery: priorities of the spinal cord-injured population. Journal of neurotrauma. 2004; 21:1371-1383. [PubMed: 15672628]

Apostolidis A, Popat R, Yiangou Y, Cockayne D, Ford AP, Davis JB, Dasgupta P, Fowler CJ, Anand P. Decreased sensory receptors $\mathrm{P} 2 \times 3$ and TRPV1 in suburothelial nerve fibers following intradetrusor injections of botulinum toxin for human detrusor overactivity. J Urol. 2005; 174:977-982. discussion 982-973. [PubMed: 16094018]

Armbruster BN, Li X, Pausch MH, Herlitze S, Roth BL. Evolving the lock to fit the key to create a family of $\mathrm{G}$ protein-coupled receptors potently activated by an inert ligand. Proc Natl Acad Sci U S A. 2007; 104:5163-5168. [PubMed: 17360345] 
Arnold JM, Feng QP, Delaney GA, Teasell RW. Autonomic dysreflexia in tetraplegic patients: evidence for alpha-adrenoceptor hyper-responsiveness. Clin Auton Res. 1995; 5:267-270. [PubMed: 8563459]

Baeyens N, Nicoli S, Coon BG, Ross TD, Van den Dries K, Han J, Lauridsen HM, Mejean CO, Eichmann A, Thomas JL, Humphrey JD, Schwartz MA. Vascular remodeling is governed by a VEGFR3-dependent fluid shear stress set point. Elife. 2015:4.

Bakhit C, Armanini M, Wong WL, Bennett GL, Wrathall JR. Increase in nerve growth factor-like immunoreactivity and decrease in choline acetyltransferase following contusive spinal cord injury. Brain Res. 1991; 554:264-271. [PubMed: 1933308]

Barth E, Albuszies G, Baumgart K, Matejovic M, Wachter U, Vogt J, Radermacher P, Calzia E. Glucose metabolism and catecholamines. Crit Care Med. 2007; 35:S508-518. [PubMed: 17713401]

Biering-Sorensen F, Bohr HH, Schaadt OP. Longitudinal study of bone mineral content in the lumbar spine, the forearm and the lower extremities after spinal cord injury. Eur J Clin Invest. 1990; 20:330-335. [PubMed: 2114994]

Birder LA, Nakamura Y, Kiss S, Nealen ML, Barrick S, Kanai AJ, Wang E, Ruiz G, De Groat WC, Apodaca G, Watkins S, Caterina MJ. Altered urinary bladder function in mice lacking the vanilloid receptor TRPV1. Nature neuroscience. 2002; 5:856-860. [PubMed: 12161756]

Bjelakovic B, Dimitrijevic L, Lukic S, Golubovic E. Hypertensive encephalopathy as a late complication of autonomic dysreflexia in a 12-year-old boy with a previous spinal cord injury. Eur J Pediatr. 2014; 173:1683-1684. [PubMed: 24535713]

Bjurholm A, Kreicbergs A, Terenius L, Goldstein M, Schultzberg M. Neuropeptide Y-, tyrosine hydroxylase- and vasoactive intestinal polypeptide-immunoreactive nerves in bone and surrounding tissues. J Auton Nerv Syst. 1988; 25:119-125. [PubMed: 2906951]

Blackmer J. Rehabilitation medicine: 1. Autonomic dysreflexia. CMAJ. 2003; 169:931-935. [PubMed: 14581313]

Bluvshtein V, Korczyn AD, Pinhas I, Vered Y, Gelernter I, Catz A. Insulin resistance in tetraplegia but not in mid-thoracic paraplegia: is the mid-thoracic spinal cord involved in glucose regulation? Spinal cord. 2011; 49:648-652. [PubMed: 21042331]

Braddom RL, Rocco JF. Autonomic dysreflexia. A survey of current treatment. Am J Phys Med Rehabil. 1991; 70:234-241. [PubMed: 1910647]

Brock JA, Yeoh M, McLachlan EM. Enhanced neurally evoked responses and inhibition of norepinephrine reuptake in rat mesenteric arteries after spinal transection. Am J Physiol Heart Circ Physiol. 2006; 290:H398-405. [PubMed: 16143650]

Brommer B, Engel O, Kopp MA, Watzlawick R, Muller S, Pruss H, Chen Y, DeVivo MJ, Finkenstaedt FW, Dirnagl U, Liebscher T, Meisel A, Schwab JM. Spinal cord injury-induced immune deficiency syndrome enhances infection susceptibility dependent on lesion level. Brain. 2016; 139:692-707. [PubMed: 26754788]

Brown A, Ricci MJ, Weaver LC. NGF message and protein distribution in the injured rat spinal cord. Experimental neurology. 2004; 188:115-127. [PubMed: 15191808]

Cabot JB, Alessi V, Carroll J, Ligorio M. Spinal cord lamina V and lamina VII interneuronal projections to sympathetic preganglionic neurons. The Journal of comparative neurology. 1994; 347:515-530. [PubMed: 7814672]

Calaresu FR, Yardley CP. Medullary basal sympathetic tone. Annu Rev Physiol. 1988; 50:511-524. [PubMed: 3288103]

Cameron AA, Smith GM, Randall DC, Brown DR, Rabchevsky AG. Genetic manipulation of intraspinal plasticity after spinal cord injury alters the severity of autonomic dysreflexia. The Journal of neuroscience : the official journal of the Society for Neuroscience. 2006; 26:2923-2932. [PubMed: 16540569]

Campagnolo DI, Bartlett JA, Keller SE, Sanchez W, Oza R. Impaired phagocytosis of Staphylococcus aureus in complete tetraplegics. Am J Phys Med Rehabil. 1997; 76:276-280. [PubMed: 9267186]

Campagnolo DI, Keller SE, DeLisa JA, Glick TJ, Sipski ML, Schleifer SJ. Alteration of immune system function in tetraplegics. A pilot study. Am J Phys Med Rehabil. 1994; 73:387-393. [PubMed: 7993612] 
Cano G, Sved AF, Rinaman L, Rabin BS, Card JP. Characterization of the central nervous system innervation of the rat spleen using viral transneuronal tracing. The Journal of comparative neurology. 2001; 439:1-18. [PubMed: 11579378]

Canon S, Shera A, Phan NM, Lapicz L, Scheidweiler T, Batchelor L, Swearingen C. Autonomic dysreflexia during urodynamics in children and adolescents with spinal cord injury or severe neurologic disease. J Pediatr Urol. 2015; 11:31-34. 32. [PubMed: 25459389]

Caruso D, Gater D, Harnish C. Prevention of recurrent autonomic dysreflexia: a survey of current practice. Clin Auton Res. 2015; 25:293-300. [PubMed: 26280219]

Cavero I, Roach AG. The pharmacology of prazosin, a novel antihypertensive agent. Life Sci. 1980; 27:1525-1540. [PubMed: 6255278]

Chalmers J, Arnolda L, Llewellyn-Smith I, Minson J, Pilowsky P, Suzuki S. Central neurons and neurotransmitters in the control of blood pressure. Clin Exp Pharmacol Physiol. 1994; $21: 819$ 829. [PubMed: 7867233]

Chobanian AV, Bakris GL, Black HR, Cushman WC, Green LA, Izzo JL, Jones DW, Materson BJ, Oparil S, Wright JT, Roccella EJ. Seventh Report of the Joint National Committee on Prevention, Detection, Evaluation, and Treatment of High Blood Pressure. Hypertension. 2003; 42:1206-1252. [PubMed: 14656957]

Clarke HA, Dekaban GA, Weaver LC. Identification of lamina V and VII interneurons presynaptic to adrenal sympathetic preganglionic neurons in rats using a recombinant herpes simplex virus type 1. Neuroscience. 1998; 85:863-872. [PubMed: 9639279]

Cockayne DA, Hamilton SG, Zhu QM, Dunn PM, Zhong Y, Novakovic S, Malmberg AB, Cain G, Berson A, Kassotakis L, Hedley L, Lachnit WG, Burnstock G, McMahon SB, Ford AP. Urinary bladder hyporeflexia and reduced pain-related behaviour in P2×3-deficient mice. Nature. 2000; 407:1011-1015. [PubMed: 11069181]

Coderre TJ, Kumar N, Lefebvre CD, Yu JS. Evidence that gabapentin reduces neuropathic pain by inhibiting the spinal release of glutamate. J Neurochem. 2005; 94:1131-1139. [PubMed: 16092950]

Coderre TJ, Kumar N, Lefebvre CD, Yu JS. A comparison of the glutamate release inhibition and antiallodynic effects of gabapentin, lamotrigine, and riluzole in a model of neuropathic pain. $\mathrm{J}$ Neurochem. 2007; 100:1289-1299. [PubMed: 17241130]

Colachis SC 3rd, Clinchot DM. Autonomic hyperreflexia associated with recurrent cardiac arrest: case report. Spinal cord. 1997; 35:256-257. [PubMed: 9143091]

Collins HL, Rodenbaugh DW, DiCarlo SE. Spinal cord injury alters cardiac electrophysiology and increases the susceptibility to ventricular arrhythmias. Prog Brain Res. 2006; 152:275-288. [PubMed: 16198707]

Consortium for Spinal Cord, M. Acute management of autonomic dysreflexia: individuals with spinal cord injury presenting to health-care facilities. J Spinal Cord Med. 2002; 25(Suppl 1):S67-88. [PubMed: 12051242]

Cragg JJ, Noonan VK, Krassioukov A, Borisoff J. Cardiovascular disease and spinal cord injury: results from a national population health survey. Neurology. 2013; 81:723-728. [PubMed: 23884034]

Curt A, Nitsche B, Rodic B, Schurch B, Dietz V. Assessment of autonomic dysreflexia in patients with spinal cord injury. J Neurol Neurosurg Psychiatry. 1997; 62:473-477. [PubMed: 9153603]

Davidoff GN, Roth EJ, Haughton JS, Ardner MS. Cognitive dysfunction in spinal cord injury patients: sensitivity of the Functional Independence Measure subscales vs neuropsychologic assessment. Archives of physical medicine and rehabilitation. 1990; 71:326-329. [PubMed: 2327886]

Denes A, Boldogkoi Z, Uhereczky G, Hornyak A, Rusvai M, Palkovits M, Kovacs KJ. Central autonomic control of the bone marrow: multisynaptic tract tracing by recombinant pseudorabies virus. Neuroscience. 2005; 134:947-963. [PubMed: 15994021]

Deuchars SA, Brooke RE, Frater B, Deuchars J. Properties of interneurones in the intermediolateral cell column of the rat spinal cord: role of the potassium channel subunit Kv3.1. Neuroscience. 2001; 106:433-446. [PubMed: 11566512]

Deuchars SA, Lall VK. Sympathetic preganglionic neurons: properties and inputs. Compr Physiol. 2015; 5:829-869. [PubMed: 25880515] 
Ditunno JF, Little JW, Tessler A, Burns AS. Spinal shock revisited: a four-phase model. Spinal cord. 2004; 42:383-395. [PubMed: 15037862]

Dolly O. Synaptic transmission: inhibition of neurotransmitter release by botulinum toxins. Headache. 2003; 43(Suppl 1):S16-24. [PubMed: 12887390]

Duckworth WC, Solomon SS, Jallepalli P, Heckemeyer C, Finnern J, Powers A. Glucose intolerance due to insulin resistance in patients with spinal cord injuries. Diabetes. 1980; 29:906-910. [PubMed: 7429029]

Dykstra DD. Botulinum toxin in the management of bowel and bladder function in spinal cord injury and other neurologic disorders. Phys Med Rehabil Clin N Am. 2003; 14:793-804. vi. [PubMed: 14580038]

Dykstra DD, Sidi AA, Anderson LC. The effect of nifedipine on cystoscopy-induced autonomic hyperreflexia in patients with high spinal cord injuries. J Urol. 1987; 138:1155-1157. [PubMed: 3669159]

Dykstra DD, Sidi AA, Scott AB, Pagel JM, Goldish GD. Effects of botulinum A toxin on detrusorsphincter dyssynergia in spinal cord injury patients. J Urol. 1988; 139:919-922. [PubMed: 3361663]

Elkelini MS, Bagli DJ, Fehlings M, Hassouna M. Effects of intravesical onabotulinumtoxinA on bladder dysfunction and autonomic dysreflexia after spinal cord injury: role of nerve growth factor. BJU Int. 2012; 109:402-407. [PubMed: 21733076]

Eltorai I, Kim R, Vulpe M, Kasravi H, Ho W. Fatal cerebral hemorrhage due to autonomic dysreflexia in a tetraplegic patient: case report and review. Paraplegia. 1992; 30:355-360. [PubMed: 1598177]

Engeland WC, Arnhold MM. Neural circuitry in the regulation of adrenal corticosterone rhythmicity. Endocrine. 2005; 28:325-332. [PubMed: 16388123]

Erickson RP. Autonomic hyperreflexia: pathophysiology and medical management. Archives of physical medicine and rehabilitation. 1980; 61:431-440. [PubMed: 6107074]

Eroglu C, Allen NJ, Susman MW, O’Rourke NA, Park CY, Ozkan E, Chakraborty C, Mulinyawe SB, Annis DS, Huberman AD, Green EM, Lawler J, Dolmetsch R, Garcia KC, Smith SJ, Luo ZD, Rosenthal A, Mosher DF, Barres BA. Gabapentin receptor alpha2delta-1 is a neuronal thrombospondin receptor responsible for excitatory CNS synaptogenesis. Cell. 2009; 139:380 392. [PubMed: 19818485]

Esmail Z, Shalansky KF, Sunderji R, Anton H, Chambers K, Fish W. Evaluation of captopril for the management of hypertension in autonomic dysreflexia: a pilot study. Archives of physical medicine and rehabilitation. 2002; 83:604-608. [PubMed: 11994798]

Fausel RA, Paski SC. Autonomic Dysreflexia Resulting in Seizure After Colonoscopy in a Patient With Spinal Cord Injury. ACG Case Rep J. 2014; 1:187-188. [PubMed: 26157871]

Fougere RJ, Currie KD, Nigro MK, Stothers L, Rapoport D, Krassioukov AV. Reduction in BladderRelated Autonomic Dysreflexia after OnabotulinumtoxinA Treatment in Spinal Cord Injury. Journal of neurotrauma. 2016

Frankel HL, Michaelis LS, Golding DR, Beral V. The blood pressure in paraplegia. I. Paraplegia. 1972; 10:193-200. [PubMed: 4636920]

Furlan JC, Fehlings MG. Cardiovascular complications after acute spinal cord injury: pathophysiology, diagnosis, and management. Neurosurg Focus. 2008; 25:E13.

Furlan JC, Fehlings MG, Halliday W, Krassioukov AV. Autonomic dysreflexia associated with intramedullary astrocytoma of the spinal cord. Lancet Oncol. 2003; 4:574-575. [PubMed: 12965279]

Furusawa K, Tokuhiro A, Sugiyama H, Ikeda A, Tajima F, Genda E, Uchida R, Tominaga T, Tanaka H, Magara A, Sumida M. Incidence of symptomatic autonomic dysreflexia varies according to the bowel and bladder management techniques in patients with spinal cord injury. Spinal cord. 2011; 49:49-54. [PubMed: 20697419]

Gao SA, Ambring A, Lambert G, Karlsson AK. Autonomic control of the heart and renal vascular bed during autonomic dysreflexia in high spinal cord injury. Clin Auton Res. 2002; 12:457-464.

[PubMed: 12598950] 
Garshick E, Kelley A, Cohen SA, Garrison A, Tun CG, Gagnon D, Brown R. A prospective assessment of mortality in chronic spinal cord injury. Spinal cord. 2005; 43:408-416. [PubMed: 15711609]

Gee NS, Brown JP, Dissanayake VU, Offord J, Thurlow R, Woodruff GN. The novel anticonvulsant drug, gabapentin (Neurontin), binds to the alpha2delta subunit of a calcium channel. The Journal of biological chemistry. 1996; 271:5768-5776. [PubMed: 8621444]

Goldstein DS, McCarty R, Polinsky RJ, Kopin IJ. Relationship between plasma norepinephrine and sympathetic neural activity. Hypertension. 1983; 5:552-559. [PubMed: 6345364]

Gorgey AS, Dolbow DR, Dolbow JD, Khalil RK, Castillo C, Gater DR. Effects of spinal cord injury on body composition and metabolic profile - part I. J Spinal Cord Med. 2014; 37:693-702. [PubMed: 25001559]

Greenway CV, Lister GE. Capacitance effects and blood reservoir function in the splanchnic vascular bed during non-hypotensive haemorrhage and blood volume expansion in anaesthetized cats. The Journal of physiology. 1974; 237:279-294. [PubMed: 4825450]

Grobecker H. Pharmacology and clinical pharmacology of organic nitrates. Eur J Clin Pharmacol. 1990; 38(Suppl 1):S3-7. [PubMed: 1972358]

Guttmann L, Whitteridge D. Effects of bladder distension on autonomic mechanisms after spinal cord injuries. Brain. 1947; 70:361-404. [PubMed: 18903252]

Guyenet P, Cabot J. Inhibition of sympathetic preganglionic neurons by catecholamines and clonidine: mediation by an alpha-adrenergic receptor. The Journal of Neuroscience. 1981; 1:908-917. [PubMed: 6286903]

Hickey KJ, Vogel LC, Willis KM, Anderson CJ. Prevalence and etiology of autonomic dysreflexia in children with spinal cord injuries. J Spinal Cord Med. 2004; 27(Suppl 1):S54-60. [PubMed: 15503704]

Hosoya Y, Nadelhaft I, Wang D, Kohno K. Thoracolumbar sympathetic preganglionic neurons in the dorsal commissural nucleus of the male rat: an immunohistochemical study using retrograde labeling of cholera toxin subunit B. Exp Brain Res. 1994; 98:21-30. [PubMed: 8013588]

Hosoya Y, Sugiura Y, Okado N, Loewy AD, Kohno K. Descending input from the hypothalamic paraventricular nucleus to sympathetic preganglionic neurons in the rat. Exp Brain Res. 1991; 85:10-20. [PubMed: 1884750]

Hou S, Duale H, Cameron AA, Abshire SM, Lyttle TS, Rabchevsky AG. Plasticity of lumbosacral propriospinal neurons is associated with the development of autonomic dysreflexia after thoracic spinal cord transection. The Journal of comparative neurology. 2008; 509:382-399. [PubMed: 18512692]

Hou S, Duale H, Rabchevsky AG. Intraspinal sprouting of unmyelinated pelvic afferents after complete spinal cord injury is correlated with autonomic dysreflexia induced by visceral pain. Neuroscience. 2009; 159:369-379. [PubMed: 19146928]

Huang YJ, Lee KH, Murphy L, Garraway SM, Grau JW. Acute spinal cord injury (SCI) transforms how GABA affects nociceptive sensitization. Experimental neurology. 2016; 285:82-95. [PubMed: 27639636]

Hubli M, Gee CM, Krassioukov AV. Refined assessment of blood pressure instability after spinal cord injury. Am J Hypertens. 2015; 28:173-181. [PubMed: 24990527]

Hubli M, Krassioukov AV. Ambulatory blood pressure monitoring in spinal cord injury: clinical practicability. Journal of neurotrauma. 2014; 31:789-797. [PubMed: 24175653]

Irwin MR, Cole SW. Reciprocal regulation of the neural and innate immune systems. Nat Rev Immunol. 2011; 11:625-632. [PubMed: 21818124]

Iversen PO, Hjeltnes N, Holm B, Flatebo T, Strom-Gundersen I, Ronning W, Stanghelle J, Benestad HB. Depressed immunity and impaired proliferation of hematopoietic progenitor cells in patients with complete spinal cord injury. Blood. 2000; 96:2081-2083. [PubMed: 10979951]

Iyer SM, Vesuna S, Ramakrishnan C, Huynh K, Young S, Berndt A, Lee SY, Gorini CJ, Deisseroth K, Delp SL. Optogenetic and chemogenetic strategies for sustained inhibition of pain. Sci Rep. 2016; 6:30570. [PubMed: 27484850]

Jaillon P. Clinical pharmacokinetics of prazosin. Clin Pharmacokinet. 1980; 5:365-376. [PubMed: 6994981] 
Jain A, Ghai B, Jain K, Makkar JK, Mangal K, Sampley S. Severe autonomic dysreflexia induced cardiac arrest under isoflurane anesthesia in a patient with lower thoracic spine injury. $\mathrm{J}$ Anaesthesiol Clin Pharmacol. 2013; 29:241-243. [PubMed: 23878450]

Jansen AS, Nguyen XV, Karpitskiy V, Mettenleiter TC, Loewy AD. Central command neurons of the sympathetic nervous system: basis of the fight-or-flight response. Science. 1995; 270:644-646. [PubMed: 7570024]

Joshi S, Levatte MA, Dekaban GA, Weaver LC. Identification of spinal interneurons antecedent to adrenal sympathetic preganglionic neurons using trans-synaptic transport of herpes simplex virus type 1. Neuroscience. 1995; 65:893-903. [PubMed: 7609886]

Jung WC, Levesque JP, Ruitenberg MJ. It takes nerve to fight back: The significance of neural innervation of the bone marrow and spleen for immune function. Semin Cell Dev Biol. 2017; 61:60-70. [PubMed: 27523920]

Karlsson AK. Autonomic dysreflexia. Spinal cord. 1999; 37:383. [PubMed: 10432257]

Karlsson AK, Elam M, Friberg P, Sullivan L, Attvall S, Lonnroth P. Peripheral afferent stimulation of decentralized sympathetic neurons activates lipolysis in spinal cord-injured subjects. Metabolism. 1997; 46:1465-1469. [PubMed: 9439544]

Kewalramani LS. Autonomic dysreflexia in traumatic myelopathy. Am J Phys Med. 1980; 59:1-21. [PubMed: 6986791]

Kinoshita M, Matsui R, Kato S, Hasegawa T, Kasahara H, Isa K, Watakabe A, Yamamori T, Nishimura Y, Alstermark B, Watanabe D, Kobayashi K, Isa T. Genetic dissection of the circuit for hand dexterity in primates. Nature. 2012; 487:235-238. [PubMed: 22722837]

Krassioukov A, Warburton DE, Teasell R, Eng JJ. Spinal Cord Injury Rehabilitation Evidence Research, T. A systematic review of the management of autonomic dysreflexia after spinal cord injury. Archives of physical medicine and rehabilitation. 2009; 90:682-695. [PubMed: 19345787]

Krassioukov AV, Bunge RP, Pucket WR, Bygrave MA. The changes in human spinal sympathetic preganglionic neurons after spinal cord injury. Spinal cord. 1999; 37:6-13. [PubMed: 10025688]

Krassioukov AV, Furlan JC, Fehlings MG. Autonomic dysreflexia in acute spinal cord injury: an under-recognized clinical entity. Journal of neurotrauma. 2003; 20:707-716. [PubMed: 12965050]

Krassioukov AV, Harkema SJ. Effect of harness application and postural changes on cardiovascular parameters of individuals with spinal cord injury. Spinal cord. 2006; 44:780-786. [PubMed: 16801934]

Krassioukov AV, Johns DG, Schramm LP. Sensitivity of sympathetically correlated spinal interneurons, renal sympathetic nerve activity, and arterial pressure to somatic and visceral stimuli after chronic spinal injury. Journal of neurotrauma. 2002; 19:1521-1529. [PubMed: 12542854]

Krassioukov AV, Weaver LC. Episodic hypertension due to autonomic dysreflexia in acute and chronic spinal cord-injured rats. American Journal of Physiology - Heart and Circulatory Physiology. 1995; 268:H2077-H2083.

Krassioukov AV, Weaver LC. Morphological changes in sympathetic preganglionic neurons after spinal cord injury in rats. Neuroscience. 1996; 70:211-225. [PubMed: 8848126]

Krenz NR, Meakin SO, Krassioukov AV, Weaver LC. Neutralizing intraspinal nerve growth factor blocks autonomic dysreflexia caused by spinal cord injury. The Journal of neuroscience : the official journal of the Society for Neuroscience. 1999; 19:7405-7414. [PubMed: 10460247]

Krenz NR, Weaver LC. Changes in the morphology of sympathetic preganglionic neurons parallel the development of autonomic dysreflexia after spinal cord injury in rats. Neuroscience letters. 1998a; 243:61-64. [PubMed: 9535113]

Krenz NR, Weaver LC. Sprouting of primary afferent fibers after spinal cord transection in the rat. Neuroscience. 1998b; 85:443-458. [PubMed: 9622243]

Krum H, Louis WJ, Brown DJ, Clarke SJ, Fleming JA, Howes LG. Cardiovascular and vasoactive hormone responses to bladder distension in spinal and normal man. Paraplegia. 1992a; 30:348354. [PubMed: 1598176]

Krum H, Louis WJ, Brown DJ, Howes LG. Pressor dose responses and baroreflex sensitivity in quadriplegic spinal cord injury patients. J Hypertens. 1992b; 10:245-250. [PubMed: 1315821] 
Krum H, Louis WJ, Brown DJ, Howes LG. A study of the alpha-1 adrenoceptor blocker prazosin in the prophylactic management of autonomic dysreflexia in high spinal cord injury patients. Clin Auton Res. 1992c; 2:83-88. [PubMed: 1353386]

Kulcu DG, Akbas B, Citci B, Cihangiroglu M. Autonomic dysreflexia in a man with multiple sclerosis. J Spinal Cord Med. 2009; 32:198-203. [PubMed: 19569468]

Laird AS, Carrive P, Waite PM. Cardiovascular and temperature changes in spinal cord injured rats at rest and during autonomic dysreflexia. The Journal of physiology. 2006; 577:539-548. [PubMed: 16973703]

Laskey W, Polosa C. Characteristics of the sympathetic preganglionic neuron and its synaptic input. Progress in neurobiology. 1988; 31:47-84. [PubMed: 3287455]

Lee JS, Fang SY, Roan JN, Jou IM, Lam CF. Spinal cord injury enhances arterial expression and reactivity of alpha1-adrenergic receptors-mechanistic investigation into autonomic dysreflexia. Spine J. 2016; 16:65-71. [PubMed: 26433037]

Lindan R, Joiner E, Freehafer A, Hazel C. Incidence and clinical features of autonomic dysreflexia in patients with spinal cord injury. Spinal cord. 1980; 18:285-292.

Llewellyn-Smith IJ. Anatomy of synaptic circuits controlling the activity of sympathetic preganglionic neurons. J Chem Neuroanat. 2009; 38:231-239. [PubMed: 19524034]

Llewellyn-Smith IJ, Weaver LC. Changes in synaptic inputs to sympathetic preganglionic neurons after spinal cord injury. The Journal of comparative neurology. 2001; 435:226-240. [PubMed: 11391643]

Lockwood G, Durkee C, Groth T. Intravesical Botulinum Toxin for Persistent Autonomic Dysreflexia in a Pediatric Patient. Case Rep Urol. 2016; 2016:4569684. [PubMed: 27006855]

Lorton D, Bellinger DL. Molecular mechanisms underlying beta-adrenergic receptor-mediated crosstalk between sympathetic neurons and immune cells. Int J Mol Sci. 2015; 16:5635-5665. [PubMed: 25768345]

Loukas M, Klaassen Z, Merbs W, Tubbs RS, Gielecki J, Zurada A. A review of the thoracic splanchnic nerves and celiac ganglia. Clin Anat. 2010; 23:512-522. [PubMed: 20235178]

Lucin KM, Sanders VM, Jones TB, Malarkey WB, Popovich PG. Impaired antibody synthesis after spinal cord injury is level dependent and is due to sympathetic nervous system dysregulation. Experimental neurology. 2007; 207:75-84. [PubMed: 17597612]

Maiorov DN, Krenz NR, Krassioukov AV, Weaver LC. Role of spinal NMDA and AMPA receptors in episodic hypertension in conscious spinal rats. Am J Physiol. 1997; 273:H1266-1274. [PubMed: 9321815]

Maruyama Y, Mizuguchi M, Yaginuma T, Kusaka M, Yoshida H, Yokoyama K, Kasahara Y, Hosoya T. Serum leptin, abdominal obesity and the metabolic syndrome in individuals with chronic spinal cord injury. Spinal cord. 2008; 46:494-499. [PubMed: 18209743]

Mathias CJ, Christensen NJ, Corbett JL, Frankel HL, Spalding JM. Plasma catecholamines during paroxysmal neurogenic hypertension in quadriplegic man. Circ Res. 1976; 39:204-208. [PubMed: 939005]

Mathias CJ, Christensen NJ, Frankel HL, Spalding JM. Cardiovascular control in recently injured tetraplegics in spinal shock. Q J Med. 1979; 48:273-287. [PubMed: 504551]

Mathias CJ, Frankel HL. Cardiovascular control in spinal man. Annu Rev Physiol. 1988; 50:577-592. [PubMed: 3288107]

Matsushita M. Ascending propriospinal afferents to area X (substantia grisea centralis) of the spinal cord in the rat. Exp Brain Res. 1998; 119:356-366. [PubMed: 9551836]

Mayorov DN, Adams MA, Krassioukov AV. Telemetric blood pressure monitoring in conscious rats before and after compression injury of spinal cord. Journal of neurotrauma. 2001; 18:727-736. [PubMed: 11497098]

McBride F, Quah SP, Scott ME, Dinsmore WW. Tripling of blood pressure by sexual stimulation in a man with spinal cord injury. J R Soc Med. 2003; 96:349-350. [PubMed: 12835450]

Moeller BA Jr, Scheinberg D. Autonomic dysreflexia in injuries below the sixth thoracic segment. JAMA. 1973; 224:1295.

Moncada S, Higgs A. The L-arginine-nitric oxide pathway. N Engl J Med. 1993; 329:2002-2012. [PubMed: 7504210] 
Muzumdar AS. The mass reflex: an emergency in a quadriplegic patients. Can Med Assoc J. 1982; 126:369-370. 376. [PubMed: 7066793]

Myers J, Lee M, Kiratli J. Cardiovascular disease in spinal cord injury: an overview of prevalence, risk, evaluation, and management. Am J Phys Med Rehabil. 2007; 86:142-152. [PubMed: 17251696]

Olive JL, Dudley GA, McCully KK. Vascular remodeling after spinal cord injury. Med Sci Sports Exerc. 2003; 35:901-907. [PubMed: 12783036]

Orasanu B, Mahajan ST. The use of botulinum toxin for the treatment of overactive bladder syndrome. Indian J Urol. 2013; 29:2-11. [PubMed: 23671356]

Pascual JI, Insausti R, Gonzalo LM. Urinary bladder innervation in male rat: termination of primary afferents in the spinal cord as determined by transganglionic transport of WGA-HRP. J Urol. 1993; 150:500-504. [PubMed: 7686986]

Phillips AA, Ainslie PN, Warburton DE, Krassioukov AV. Cerebral Blood Flow Responses to Autonomic Dysreflexia in Humans with Spinal Cord Injury. Journal of neurotrauma. 2016a; 33:315-318. [PubMed: 26077616]

Phillips AA, Elliott SL, Zheng MM, Krassioukov AV. Selective alpha adrenergic antagonist reduces severity of transient hypertension during sexual stimulation after spinal cord injury. Journal of neurotrauma. 2015; 32:392-396. [PubMed: 25093677]

Phillips AA, Matin N, Frias B, Zheng MM, Jia M, West C, Dorrance AM, Laher I, Krassioukov AV. Rigid and remodelled: cerebrovascular structure and function after experimental high-thoracic spinal cord transection. The Journal of physiology. 2016b; 594:1677-1688. [PubMed: 26634420]

Phillips AA, Warburton DE, Ainslie PN, Krassioukov AV. Regional neurovascular coupling and cognitive performance in those with low blood pressure secondary to high-level spinal cord injury: improved by alpha-1 agonist midodrine hydrochloride. J Cereb Blood Flow Metab. 2014; 34:794-801. [PubMed: 24473484]

Ploumis A, Yadlapalli N, Fehlings MG, Kwon BK, Vaccaro AR. A systematic review of the evidence supporting a role for vasopressor support in acute SCI. Spinal cord. 2010; 48:356-362. [PubMed: 19935758]

Popok D, West CR, Hubli M, Currie KD, Krassioukov AV. Characterising the severity of autonomic cardiovascular dysfunction after spinal cord injury using a novel 24 hour ambulatory blood pressure analysis software. Journal of neurotrauma. 2016

Pyner S, Coote JH. Evidence that sympathetic preganglionic neurones are arranged in target-specific columns in the thoracic spinal cord of the rat. The Journal of comparative neurology. 1994; 342:15-22. [PubMed: 8207125]

Rabchevsky AG. Segmental organization of spinal reflexes mediating autonomic dysreflexia after spinal cord injury. Prog Brain Res. 2006; 152:265-274. [PubMed: 16198706]

Rabchevsky AG, Patel SP, Duale H, Lyttle TS, O’Dell CR, Kitzman PH. Gabapentin for spasticity and autonomic dysreflexia after severe spinal cord injury. Spinal cord. 2011; 49:99-105. [PubMed: 20514053]

Rabchevsky AG, Patel SP, Lyttle TS, Eldahan KC, O’Dell CR, Zhang Y, Popovich PG, Kitzman PH, Donohue KD. Effects of gabapentin on muscle spasticity and both induced as well as spontaneous autonomic dysreflexia after complete spinal cord injury. Frontiers in physiology. 2012; 3:329. [PubMed: 22934077]

Radulovic LL, Turck D, von Hodenberg A, Vollmer KO, McNally WP, DeHart PD, Hanson BJ, Bockbrader HN, Chang T. Disposition of gabapentin (neurontin) in mice, rats, dogs, and monkeys. Drug Metab Dispos. 1995; 23:441-448. [PubMed: 7600909]

Rhen T, Cidlowski JA. Antiinflammatory action of glucocorticoids--new mechanisms for old drugs. N Engl J Med. 2005; 353:1711-1723. [PubMed: 16236742]

Riegger T, Conrad S, Liu K, Schluesener HJ, Adibzahdeh M, Schwab JM. Spinal cord injury-induced immune depression syndrome (SCI-IDS). Eur J Neurosci. 2007; 25:1743-1747. [PubMed: 17432962]

Rizzoni D, Porteri E, Boari GE, De Ciuceis C, Sleiman I, Muiesan ML, Castellano M, Miclini M, Agabiti-Rosei E. Prognostic significance of small-artery structure in hypertension. Circulation. 2003; 108:2230-2235. [PubMed: 14557363] 
Rowell LB. Importance of scintigraphic measurements of human splanchnic blood volume. J Nucl Med. 1990; 31:160-162. [PubMed: 2313354]

Rummery NM, Tripovic D, McLachlan EM, Brock JA. Sympathetic vasoconstriction is potentiated in arteries caudal but not rostral to a spinal cord transection in rats. Journal of neurotrauma. 2010; 27:2077-2089. [PubMed: 20822463]

Sabre L, Rekand T, Asser T, Korv J. Mortality and causes of death after traumatic spinal cord injury in Estonia. J Spinal Cord Med. 2013; 36:687-694. [PubMed: 24090049]

Schiffrin EL. Remodeling of resistance arteries in essential hypertension and effects of antihypertensive treatment. Am J Hypertens. 2004; 17:1192-1200. [PubMed: 15607629]

Schnegelsberg B, Sun TT, Cain G, Bhattacharya A, Nunn PA, Ford AP, Vizzard MA, Cockayne DA. Overexpression of NGF in mouse urothelium leads to neuronal hyperinnervation, pelvic sensitivity, and changes in urinary bladder function. Am J Physiol Regul Integr Comp Physiol. 2010; 298:R534-547. [PubMed: 20032263]

Schramm LP. Spinal sympathetic interneurons: their identification and roles after spinal cord injury. Prog Brain Res. 2006; 152:27-37. [PubMed: 16198691]

Schurch B, de Seze M, Denys P, Chartier-Kastler E, Haab F, Everaert K, Plante P, Perrouin-Verbe B, Kumar C, Fraczek S, Brin MF. Botox Detrusor Hyperreflexia Study, T. Botulinum toxin type a is a safe and effective treatment for neurogenic urinary incontinence: results of a single treatment, randomized, placebo controlled 6-month study. J Urol. 2005; 174:196-200. [PubMed: 15947626]

Schurch B, Hauri D, Rodic B, Curt A, Meyer M, Rossier AB. Botulinum-A toxin as a treatment of detrusor-sphincter dyssynergia: a prospective study in 24 spinal cord injury patients. J Urol. 1996; 155:1023-1029. [PubMed: 8583552]

Schurch B, Stohrer M, Kramer G, Schmid DM, Gaul G, Hauri D. Botulinum-A toxin for treating detrusor hyperreflexia in spinal cord injured patients: a new alternative to anticholinergic drugs? Preliminary results. J Urol. 2000; 164:692-697. [PubMed: 10953127]

Scott MB, Morrow JW. Phenoxybenzamine in neurogenic bladder dysfunction after spinal cord injury. II. Autonomic dysreflexia. J Urol. 1978; 119:483-484. [PubMed: 650750]

Shimoyama M, Shimoyama N, Hori Y. Gabapentin affects glutamatergic excitatory neurotransmission in the rat dorsal horn. Pain. 2000; 85:405-414. [PubMed: 10781913]

Showkathali R, Antionios TF. Autonomic dysreflexia; a medical emergency. J R Soc Med. 2007; 100:382-383. [PubMed: 17682033]

Silver AE, Vita JA. Shear-stress-mediated arterial remodeling in atherosclerosis: too much of a good thing? Circulation. 2006; 113:2787-2789. [PubMed: 16785350]

Silver JR. Early autonomic dysreflexia. Spinal cord. 2000; 38:229-233. [PubMed: 10822393]

Snow JC, Sideropoulos HP, Kripke BJ, Freed MM, Shah NK, Schlesinger RM. Autonomic hyperreflexia during cystoscopy in patients with high spinal cord injuries. Paraplegia. 1978; 15:327-332. [PubMed: 625432]

Stachniak TJ, Ghosh A, Sternson SM. Chemogenetic synaptic silencing of neural circuits localizes a hypothalamus-->midbrain pathway for feeding behavior. Neuron. 2014; 82:797-808. [PubMed: 24768300]

Stjernberg L, Blumberg H, Wallin BG. Sympathetic activity in man after spinal cord injury. Outflow to muscle below the lesion. Brain. 1986; 109(Pt 4):695-715. [PubMed: 3730811]

Strack AM, Sawyer WB, Hughes JH, Platt KB, Loewy AD. A general pattern of CNS innervation of the sympathetic outflow demonstrated by transneuronal pseudorabies viral infections. Brain Res. 1989; 491:156-162. [PubMed: 2569907]

Sved AF, Cano G, Card JP. Neuroanatomical specificity of the circuits controlling sympathetic outflow to different targets. Clin Exp Pharmacol Physiol. 2001; 28:115-119. [PubMed: 11153526]

Tang FR, Tan CK, Ling EA. A light-microscopic study of the intermediolateral nucleus following injection of CB-HRP and fluorogold into the superior cervical ganglion of the rat. J Auton Nerv Syst. 1995; 50:333-338. [PubMed: 7714327]

Tang X, Neckel ND, Schramm LP. Spinal interneurons infected by renal injection of pseudorabies virus in the rat. Brain Res. 2004a; 1004:1-7. [PubMed: 15033414] 
Tang XQ, Tanelian DL, Smith GM. Semaphorin3A inhibits nerve growth factor-induced sprouting of nociceptive afferents in adult rat spinal cord. The Journal of neuroscience : the official journal of the Society for Neuroscience. 2004b; 24:819-827. [PubMed: 14749426]

Thomas GD. Neural control of the circulation. Adv Physiol Educ. 2011; 35:28-32. [PubMed: 21385998]

Thyberg M, Ertzgaard P, Gylling M, Granerus G. Effect of nifedipine on cystometry-induced elevation of blood pressure in patients with a reflex urinary bladder after a high level spinal cord injury. Paraplegia. 1994; 32:308-313. [PubMed: 8058347]

Trop CS, Bennett CJ. Autonomic dysreflexia and its urological implications: a review. J Urol. 1991; 146:1461-1469. [PubMed: 1942319]

Ueno M, Ueno-Nakamura Y, Niehaus J, Popovich PG, Yoshida Y. Silencing spinal interneurons inhibits immune suppressive autonomic reflexes caused by spinal cord injury. Nature neuroscience. 2016; 19:784-787. [PubMed: 27089020]

Valles M, Benito J, Portell E, Vidal J. Cerebral hemorrhage due to autonomic dysreflexia in a spinal cord injury patient. Spinal cord. 2005; 43:738-740. [PubMed: 16010281]

Vegiopoulos A, Herzig S. Glucocorticoids, metabolism and metabolic diseases. Mol Cell Endocrinol. 2007; 275:43-61. [PubMed: 17624658]

Verghese M. Autonomic dysreflexia: a life threatening emergency. Nurs J India. 1989; 80:134-135. [PubMed: 2762179]

Vizzard MA. Increased expression of spinal cord Fos protein induced by bladder stimulation after spinal cord injury. Am J Physiol Regul Integr Comp Physiol. 2000; 279:R295-305. [PubMed: 10896894]

Vollmer KO, von Hodenberg A, Kolle EU. Pharmacokinetics and metabolism of gabapentin in rat, dog and man. Arzneimittelforschung. 1986; 36:830-839. [PubMed: 3730018]

Wallin BG, Stjernberg L. Sympathetic activity in man after spinal cord injury. Outflow to skin below the lesion. Brain. 1984; 107(Pt 1):183-198. [PubMed: 6697155]

Weaver LC, Cassam AK, Krassioukov AV, Llewellyn-Smith IJ. Changes in immunoreactivity for growth associated protein-43 suggest reorganization of synapses on spinal sympathetic neurons after cord transection. Neuroscience. 1997; 81:535-551. [PubMed: 9300440]

Wecht JM, Bauman WA. Decentralized cardiovascular autonomic control and cognitive deficits in persons with spinal cord injury. J Spinal Cord Med. 2013; 36:74-81. [PubMed: 23809520]

West CR, Alyahya A, Laher I, Krassioukov A. Peripheral vascular function in spinal cord injury: a systematic review. Spinal cord. 2013; 51:10-19. [PubMed: 23184028]

West CR, Popok D, Crawford MA, Krassioukov AV. Characterizing the Temporal Development of Cardiovascular Dysfunction in Response to Spinal Cord Injury. Journal of neurotrauma. 2015; 32:922-930. [PubMed: 25630034]

West CR, Squair JW, McCracken L, Currie KD, Somvanshi R, Yuen V, Phillips AA, Kumar U, McNeill JH, Krassioukov AV. Cardiac Consequences of Autonomic Dysreflexia in Spinal Cord Injury. Hypertension. 2016

Yekutiel M, Brooks ME, Ohry A, Yarom J, Carel R. The prevalence of hypertension, ischaemic heart disease and diabetes in traumatic spinal cord injured patients and amputees. Paraplegia. 1989; 27:58-62. [PubMed: 2784200]

Zagon A, Smith AD. Monosynaptic projections from the rostral ventrolateral medulla oblongata to identified sympathetic preganglionic neurons. Neuroscience. 1993; 54:729-743. [PubMed: 8332259]

Zehnder Y, Luthi M, Michel D, Knecht H, Perrelet R, Neto I, Kraenzlin M, Zach G, Lippuner K. Long-term changes in bone metabolism, bone mineral density, quantitative ultrasound parameters, and fracture incidence after spinal cord injury: a cross-sectional observational study in 100 paraplegic men. Osteoporos Int. 2004; 15:180-189. [PubMed: 14722626]

Zhang Y, Guan Z, Reader B, Shawler T, Mandrekar-Colucci S, Huang K, Weil Z, Bratasz A, Wells J, Powell ND, Sheridan JF, Whitacre CC, Rabchevsky AG, Nash MS, Popovich PG. Autonomic dysreflexia causes chronic immune suppression after spinal cord injury. The Journal of neuroscience : the official journal of the Society for Neuroscience. 2013; 33:12970-12981. [PubMed: 23926252] 
Zhu H, Roth BL. Silencing synapses with DREADDs. Neuron. 2014; 82:723-725. [PubMed: 24853931] 


\section{Highlights}

- $\quad$ Autonomic dysreflexia (AD) is defined as episodic hypertension and concomitant baroreflex-mediated bradycardia initiated by unmodulated sympathetic reflexes in the decentralized cord.

- Herein, we review the pathophysiological mechanisms underlying the development of $\mathrm{AD}$, including maladaptive plasticity of neural circuits mediating abnormal sympathetic reflexes and hypersensitization of peripheral vasculature that collectively contribute to abnormal hemodynamics after SCI.

- Contemporary research avenues are presented to elucidate the effects of recurring $\mathrm{AD}$ on cardiovascular and immune functions for developing more targeted and effective treatments to attenuate the development of AD. 


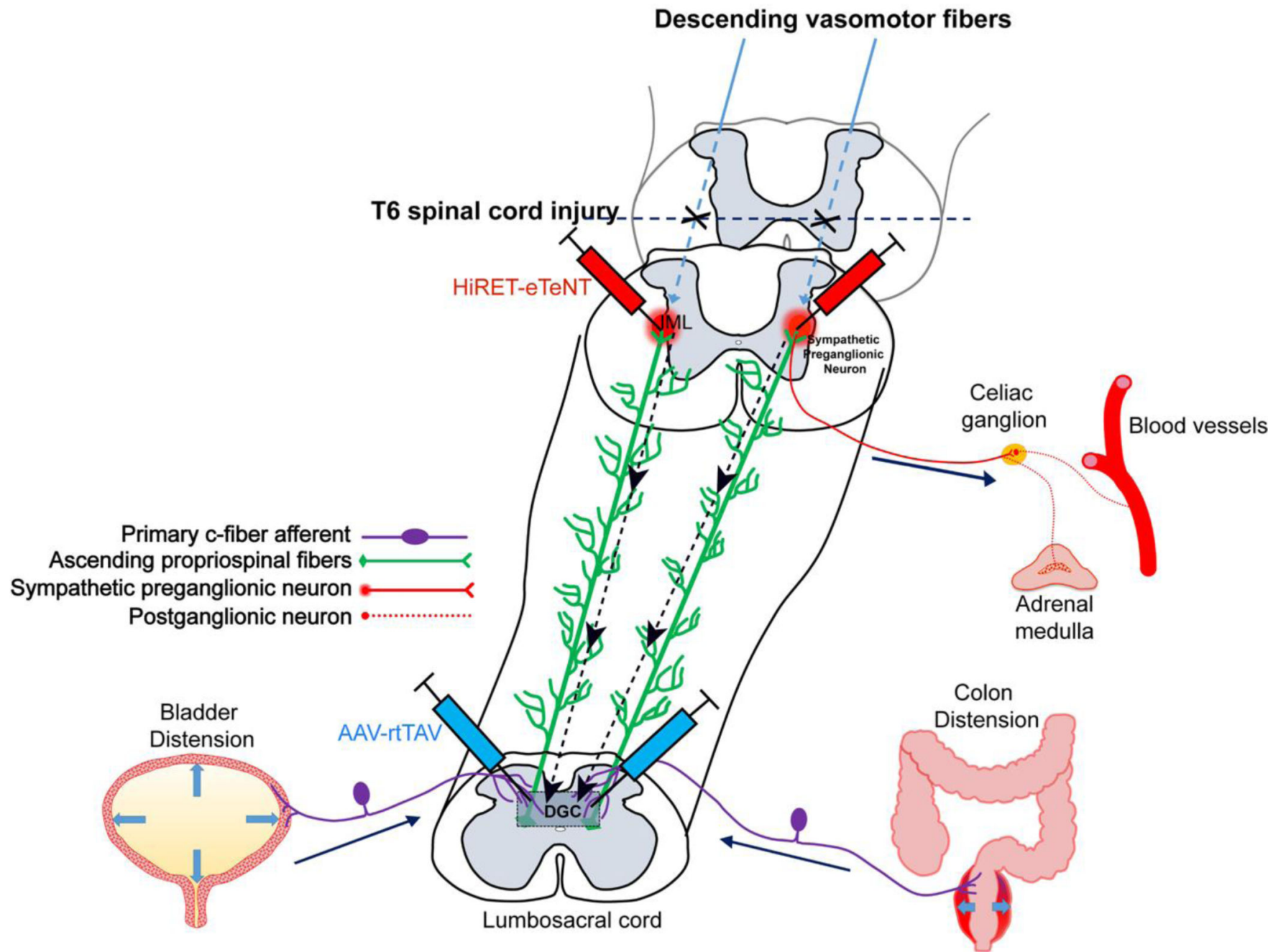

Figure 1.

Diagrammatic representation of the neuroanatomical circuitry thought to be involved in autonomic dysreflexia triggered by pelvic visceral stimulation, as well as potential neuronal pathway silencing paradigms. Descending vasomotor fibers (blue) originating in the brainstem and hypothalamus modulate the tonic activity of sympathetic preganglionic neurons (SPN; red) throughout the intermediolateral cell column (IML) in the thoracolumbar spinal cord. After complete spinal cord injury at or above the T6 segment, SPN which innervate the adrenal medulla and blood vessels below the injury are segregated from descending control pathways, allowing for unrestrained sympathetic reflex activity that leads to hypertension. Injury further leads to maladaptive sprouting of both primary afferent cfibers (purple) and ascending propriospinal tracts (green) originating in the lumbosacral dorsal gray commissure (DGC). These ascending "relay" neurons are thought to convey sensory information from the bladder and colon (i.e., distension) rostrally towards SPN. Emerging neuronal silencing techniques may allow for investigations into the role of specific neuroanatomical pathways involved in AD. One example might be to employ double infection of ascending lumbosacral propriospinal neurons with the HiRET-eTeNT vector (red syringe), which is retrogradely transported (dotted black lines) from nerve terminals in 
the IML to lumbosacral DGC also infected with AAV-rtTAV vector (blue syringe).

Doxycycline-induced silencing of these neurons could then allow for direct investigation into their roles in facilitating AD during pelvic visceral stimulation. 